\title{
コレステリン投与ラットの組織学的研究 とくに歯周組織の変化について
}

\author{
上 野 和之 \\ 東京医科歯科大学歯学部病理学教室（指導 : 石川梧朗教授）
}

(昭和 40 年 10 月 15 日受付)

\begin{abstract}
Histological studies on the Wistar rats fed Cholesterol, Sodium cholate and Methylthiouracil, with special reference to the changes of the periodontal tissues.

Kazuyuki Ueno

Department of Pathology, School of Dentistry, Tokyo Medical and

Dental University

(Director : Prof. Gorō Ishikawa)
\end{abstract}

\section{I 緒 論}

辺緑性歯周炎の病因として局所的および全身的 な種々の因子があげられているが，辺縁性歯周炎 の発現に直接関与するのは局所的因子であり，全 身的因子はそれのみでは歯周炎を発現させること は出来ず，組織の抵抗力を減弱させることにより 二次的あるいは間接的に炎症の増悪を促進させる ものであると考えられている。しかし，全身的因 子の歯周組織に及ぼす影響については未だ明らか でない点が多く、これらの点は動物実験により追 求されている。とくに新陳代謝障害と歯周疾患と の関連については，蛋白質代謝の方面から ${ }^{6,15,28}$, ${ }^{48,49)}$ ，また糖質代謝の方面から ${ }^{5,16,25,26,36,39,51,53)}$ ， 多くの研究が見られるが，脂質代謝の方面からの 検索は殆んど行なわれていない。その理由として は，第一に脂質代謝異常と歯周疾患との関連につ いては臨床的にも明らかな報告がないこと，第二 に歯周組織の構造や使用動物の数などの点からこ れらの実験に適しているラット，マウス，八ムス ターなどの動物がウサギ, ニワトリ, モルモット などの動物に比較して高コレステリン・脂肪血
症, 脂肪肝, アテローム性動脈硬化症などいわゆ る一連の全身性脂質代謝異常を起しにくいこと， 第三に組織に形態学的に認められた变化を機能的 な異常にそのまま結びつけるのが困難であること などが考えられる。

コレステリン投与実験は本来主に動脈硬化症の 発症を目的としていろいろな動物について行な われたもので，ラットについても1913 年 ${ }^{22}$ 以来 数多くの報告 ${ }^{11,43,54,65)}$ が見られる。しかし，ラッ トの場合生理的に動脈硬化症を発現しにくい動物

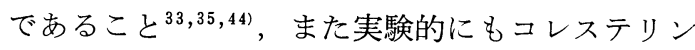
のみの投与ではアテローム性動脈硬化症の発症が 認められないとともに血中コレステリン值も他の 動物に比較して上昇し難いということ ${ }^{17,33,35,44,54)}$ が報告されている。その後研究が進むにつれて動 脈硬化症に対する動物の抵抗力の問題が論じられ るとともにコレステリン投与実験が脂質代謝の見 地からも検討され，アテローム性動脈硬化症を発 症させるためには高コレステリン血症を発症させ ることが必要となり，コレステリン投与に加えて 合成食飼育による影響 $17,35,44,54)$ ，肝内コレステリ ン動静に関する胆汁酸の役割 ${ }^{13,24,52)}$ ，体内脂質に 
対する甲状腺および脳下垂体など内分泌器官との 関連 ${ }^{21,23,34,37)}$ が論議されに至つている。このよう な研究により，ラットにおいてもコレステリン， 胆汁酸，抗甲状腺剤などを含む合成食で 飼育す ると，高コレステリン血症やアテローム性動脈 硬化症を発症させ得ることが解明された ${ }^{191}$ が, この場合ほかに脂肪肝, 心筋梗塞, 腎の梗塞, 血液凝固促進，高度の栄養障害を伴うことが 報 告されている $20,30,32,41,50,56,60,62) 。$

著者は脂質代謝異常としての高コレステリン血 症, 脂肪肝などが歯周組織に如何なる影響を及ぼ すか，また歯肉炎の増悪および辽縁性歯周炎の発 現に際し全身的因子としてなんらかの役割を演ず るか，さらにまたこの際咬合機能が変化の発現に どのような影響を及ぼすかを追求するべく試みた が，歯周組織の場合高度の栄養障害とくに飢餓的

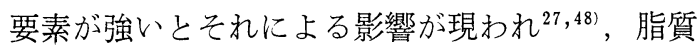
代謝異常による影響を解明することが困難になる ために, 高コレステリン血症, 脂肪肝の発症に必 要とされているコレステリン, 胆汁酸, 抗甲状腺 剤を大豆油と混じ投与し, 普通食にて飼育する以 下のような実験を行なつた。

\section{II 実験方法}

体重 $275 \pm 10 \mathrm{~g}$ の Wistar 系雄成熟 ラット 88 匹（対照群 24 匹，実験群 64 匹）を実験動物とし て用い，おのおのの左側上顎臼歯 3 本をチクロパ ンナトリウム麻酔のもとに抜去したのち，次のよ うに実験群を分類した。

1) Ch.Cs.O. 群 (32 匹) コレステリン，コール酸ソーダ，大豆油

2) Ch.Cs.mT.O. 群 (16 匹) コレステリン，コール酸ソーダ，メチル チオウラシル, 大豆油

3) Ch.mT.O. 群 (12 匹) コレステリン, メチルチオウラシル，大 豆油

4) mT.O. 群 ( 4 匹 $)$

メチルチオウラシル, 大豆油

抜歯後 1 週間たつてから薬物投与を開始した。
なお，投与法としては上記の組合わせでコレステ リンは $100 \mathrm{~g}$, コール酸ソーダは $25 \mathrm{~g}$ ，メチルオウ ラシルは $10 \mathrm{~g}$ にそれぞれ大豆油を加え混合懸濁 液の状態で $400 \mathrm{cc}$ としたものを, “B \& S ” No. 5 のゴム管により経口的に胃に注入する方法 をとつた。投与は 1 回当り $10 \mathrm{cc} / \mathrm{kg}$ 体重の割で, 週 3 回ずつ実験終了時迄規則的に行なつた。

また, 全動物とも $100 \mathrm{~g}$ 前後で購入後実験終了 時迄恒温動物室の金属ケージ内に 4 匹ずつ入れ， オリエンタル固型飼料 MF および水道水を充分 に与え, 出来るだけ同一条件のもとに飼育した。

実験期間は $3 ， 4.5 ， 6$ 力月としたが，対照群と Ch.Cs.O. 群についてはさらに 7.5, 9 力月迄観察 を行なつた。

動物の体重および摂取飼料量は週一度測定し, 各群についての平均值を算出した。

血中コレステリン值は全動物とも実験終了時 12 時間以内に心臓穿刺により得た $1 \mathrm{cc}$ の血液を 用い，Zak 氏簡易法によつて測定したほか，各 群数例については実験経過中にも同方法にて測定 し，その変動を観察した。

実験終了の動物は各群 4〜6湴(ただし，mT.O. 群では 4.5 カ月 1 例, 6 力月 3 例のみ）をクロロ ホルム麻酔のもとで剖検し，10\%中性ホルマリ ン液で澦骨および各臓器を固定した。固定後両 側下顎についてはX線写真を撮影し，Plank \& Rychlo の迅速脱灰液で脱灰したのち, クロロ丮 ルム・パラフィン法により包埋し， $6 \sim 7 \mu$ の近 遠心方向連続切片標本を作り, $\mathrm{HE}$, 銀, エラス チカ・ワンギーソン，アザン・マロリーなどの染 色をほどこした。また，下肢骨についても同様 脱灰, 包埋, 薄切後 $\mathrm{HE}$ 染色を行なつた。内臟 については通法に従いパラフィン切片標本を作 り, $\mathrm{HE}, \mathrm{PAS}$, エラスチカ・ワンギーソン, アザ ン・マロリ一染色をほどこしたほか，肝，副腎， 腎，心，肺，大動脈などについては，さらにゼラ チン包埋による氷結切片標本を作り Sudan III 染 色を行ない，且つ偏光顕微鏡をも用い，脂質およ びコレステリンの動静を観察した。 


\section{III 実 験 成 縤}

\section{A 一般的所見}

全実験期間を通じて，対照群は外見的になんら 異常を示さないが，実験群は全般的に動作が緩慢 であり, 特に Ch.Cs.O., Ch.Cs.mT.O. 両群には栄 養状態の悪い例や体毛の光沢の失われている例が しばしば見られた。また, Ch.Cs.O., Ch.Cs.mT.O. 両群には肺炎，全身衰弱などの原因で実験経過中 死亡した例が数匹あつたが，その他の群には死亡 した例は全くなかつた。

動物の体重は図1で示すように，対照群では 順調な増加が見られたが，実験群では全般的に増 加程度が低く, Ch.Cs.O., Ch.Cs.mT.O. 両群で は 実験期間 3 力月で約 $50 \mathrm{~g}, 6$ 力月で 約 $100 \mathrm{~g}$, Ch.Cs.O. 群 9 力月で約 $120 \mathrm{~g}$ 対照群より少なく なつていた。また, Ch.mT.O., mT.O. 両群では 実験期間 4 力月頃迄は対照群とほぼ同様の増加が 見られたが，その後はやや低くなり，6 月月では 約 $40 \mathrm{~g}$ 対照群より少なくなつていた。

動物の飼料摂取量は図 2 で示すように，対照群 の 22-24 g/day に対して, Ch.Cs.O., Ch.Cs.mT.O. 両群では 16-18 g/day, Ch.mT.O., mT.O. 両群で は 18-20 g/day であり，一般に実験群の方が 1 日 1 匹当りで約 $4 \sim 6 \mathrm{~g}$ 対照群より少なかつた。

\section{B 血中コレステリン值}

血中コレステリン值は表 1 で示すように，対照

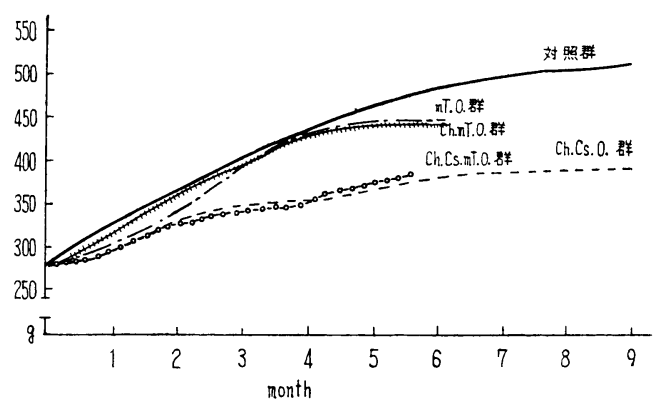

図 1 体重曲線 $\mathrm{g}$

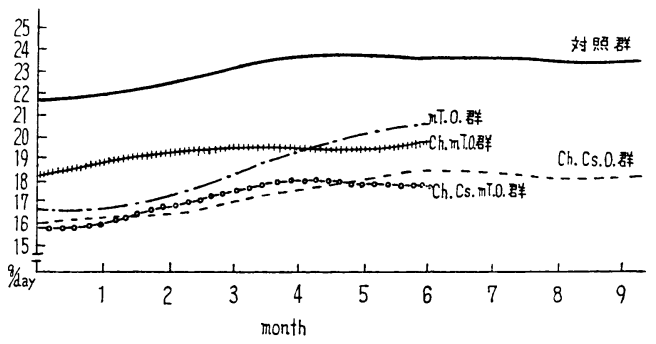

図 2 摂取飼料曲線 $g /$ day

群では実験期間 6 カ月迄は経過とともにやや上昇 するが， 7.5 カ月以降になるとむしろ下降してい るのが見られた。しかし，いずれの場合も，正常 值の範囲を越えることは全くなかつた。

実験群は，Ch.Cs.mT.O. 群で上昇が最も著明で あり，実験期間 6 力月の平均で対照群の約 4 倍の 数值を示していた。Ch.Cs.O. 群でも上昇は明ら

表 1 血中コレステリン值 $\mathrm{mg} / \mathrm{dl}$ (Zak's method)

\begin{tabular}{|c|c|c|c|c|c|c|c|c|c|c|}
\hline $\begin{array}{l}\text { Period } \\
\text { Group }\end{array}$ & $3 \mathrm{~W}$ & $1 \mathrm{M}$ & $1.5 \mathrm{M}$ & $2 \mathrm{M}$ & $3 \mathrm{M}$ & $4 \mathrm{M}$ & $4.5 \mathrm{M}$ & $6 \mathrm{M}$ & $7.5 \mathrm{M}$ & $9 \mathrm{M}$ \\
\hline 対 照 & $\begin{array}{c}80 \\
(76-82)\end{array}$ & & $\begin{array}{c}87 \\
(82-91)\end{array}$ & $\begin{array}{c}84 \\
(68-102)\end{array}$ & $\begin{array}{c}98 \\
(91-105)\end{array}$ & & $\begin{array}{c}102 \\
(98-109)\end{array}$ & $\begin{array}{c}114 \\
(97-120)\end{array}$ & $\begin{array}{c}98 \\
(95-101)\end{array}$ & $\begin{array}{c}98 \\
(86-108)\end{array}$ \\
\hline Ch.Cs. O. & $\begin{array}{c}115 \\
(105-125)\end{array}$ & & $\begin{array}{c}98 \\
(88-108)\end{array}$ & $\begin{array}{c}93 \\
(85-106)\end{array}$ & $\begin{array}{c}112 \\
(107-119)\end{array}$ & & $\begin{array}{c}134 \\
(110-212)\end{array}$ & $\begin{array}{c}335 \\
(222-398)\end{array}$ & $\begin{array}{c}205 \\
(160-230)\end{array}$ & $\begin{array}{c}253 \\
(230-288)\end{array}$ \\
\hline Ch.Cs.mT.O. & & 157 & & & $\mid \begin{array}{c}208 \\
(127-346)\end{array}$ & 248 & $\begin{array}{c}186 \\
(125-270)\end{array}$ & $\begin{array}{c}435 \\
(420-439)\end{array}$ & & \\
\hline Ch.mT.O. & & 127 & & & $\begin{array}{c}130 \\
(117-153)\end{array}$ & 142 & $\begin{array}{c}125 \\
(101-142)\end{array}$ & $\begin{array}{c}203 \\
(171-220)\end{array}$ & & \\
\hline mT.O. & & 110 & & & $\mid \begin{array}{c}114 \\
(110-119)\end{array}$ & 120 & $\left(\begin{array}{c}105 \\
(99-111)\end{array}\right.$ & $\begin{array}{c}135 \\
(111-182)\end{array}$ & & \\
\hline
\end{tabular}


かであり，6力月平均で詨照群の約 3 倍になつて いた。Ch.mT.O. 群では上昇はやや軽度であり，6 カ月平均で対照群の約 2 倍の数值を示していた。 また, mT.O. 群では 6 カ月の一部に軽度の上昇 を示した例があつたが，全般的には対照群との間 に明らなか差は認められなかつた。

\section{C 贜器}

a 肝

1. 対照群

肉眼的所見 : 各実験期間のものとも, 色は一様 に赤褐色を呈し，辺縁は鋭利で，小葉構造は明膫 に認められた。

組織学的所見 (図 $3 a$ )：全実験期間を通じて Sudan III で染め出される脂質は殆んどなく，偏 光顕微鏡下に検出されるコレステリンも胆汁中あ るいは胆管上皮中に見られる小量のものを除けば 殆んど認められなかつた。

\section{2。実験群}

肉眼的所見 :

Ch.Cs.O. 群 : 実験期間 3 カ月のものでは, 色 はやや黄色味をおびており，実験期間が長くなる につれてさらに黄色味が強くなつていた。また， 辺縁は実験期間 6 力月以降で注やや丸味をおびて いたが，小葉構造は全実験期間を通じて認められ た。

Ch.Cs.mT.O. 群：色は実験期間 3 カ月ですで
に黄色味を強くおびており，6 カ月になると一様 に黄白色を呈していた。辺縁は実験期間 3 力月で やや丸味を㧍びて㧍り，6力月ではさらに肝全体 が一様に腫脹し，小葉構造も極めて不明膫になつ ていた。

Ch.mT.O. 群：色は 実験期間が長くなるにつ れてやや黄色味をおびて来たが，各実験期間のも のとも辺縁注鋭利であり, 小葉構造も明瞭に認め られた。

mT.O. 群： 実験期間 6 力月の一部で色がやや 黄色味をおびていたのがあつたが，全般的には対 照群とほぼ同様な所見を呈していた。

組織学的所見 :

Ch.Cs.O. 群 : 実験期間 3 力月では, Sudan III 陽性の脂質は小葉周辺部にやや多量に認められ, コレステリンも同様に沈着していた。実験期間が 長くなるにつれて，脂質およびコレステリンは増 加し， 6 カ月以降になるとほぼ小葉全体に認めら れるようになつた。しかし，量的には小葉周辺部 に多く，中心部には比較的少なかつた。コレステ リンは主として小さな結晶から成つていた。ま た，全身衰弱の高度な一部の例では，中心性の脂 肪変性を併合しているのが認められたが，これら の変性部にはコレステリンは殆んど検出されなか つた。

Ch.Cs.mT.O. 群(図 3 b) : 実験期間 3 カ月です

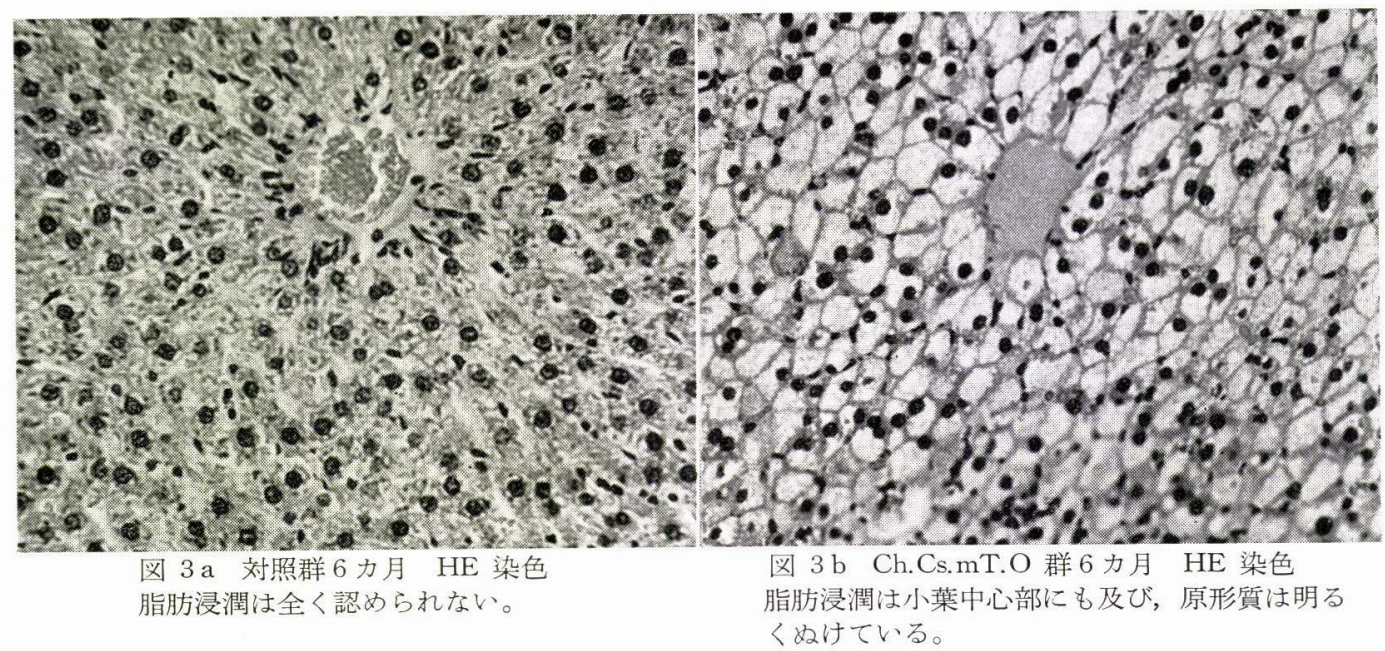


でに, 脂質は小葉全体に染め出され, コレステリ ンも同様に多量検出された。脂質およびコレステ リンは実験期間が長くなるにつれてさらに増加 し， 6 カ月では肝全体に一様な高度の浸潤が認め られた。コレステリンは大きな結晶がその大部分 を占めていた。

Ch.mT.O. 群 : 脂質およびュレステリンは小葉 周辺部に認められ，実験期間が長くなるにつれて さらに増加していたが，全般的に Ch.Cs.O. 群程 明らかではなかつた。コレステリンは小さな結晶 がその大部分を占めていた。

mT.O. 群：実験期間 6 力月では, 脂質は小葉 周辺部に散在性に染め出され，コレステリンも同 部に少量検出された。また，脂質およびコレステ リン浸潤が軽度の例でも，Kupffer の星細胞原形 質中にしばしば脂肪滴が認められた。

b 副腎皮質

1. 対照群

Sudan III で染め出される脂質ならびに偏光顕 微鏡で検出されるコレステリンは, 各実験期間の ものともほぼ同様な所見を呈していた。すなわ ち, 脂質は球状帯に少なく束状帯に多いが, 網状 帯では散在性に存在していた。また、コレステリ ンは球状帯には殆んど全くなく, 束状帯でやや多 く, 網状帯では極めて少なかつた（図 4 a)。

\section{2. 実験群}

Ch.Cs.O. 群：脂質は実験期間 3 力月ですでに 球状帯から 網状带まで 全層にわたり一様に増加 し, 実験期間が長くなるにつれてさらに増加が明 らかになつていた。またコレステリンも同様に 増加していたが，球状帯には殆んど認められなか つた。

Ch.Cs.mT.O. 群 : 脂質は実験期間 3 カ月では 球状帯から網状帯にかけてやや増加していたが, 4.5 力月以降になるとむしろ 減少を示すようにな り, 6 カ月では束状帯からの減少がやや明らかで あつた。コレステリンも脂質の増減と同様の傾向 を示していた。

Ch.mT.O. 群 : 脂質ならびにコレステリンは, 実験期間 3 力月では対照群とほぼ同様であつた
が，4.5 カ月以降になると明らかな減少を示し， 6 力月では球状帯から網状帯まで全層にわたり殆 んど認められなかつた（図 4 b)。

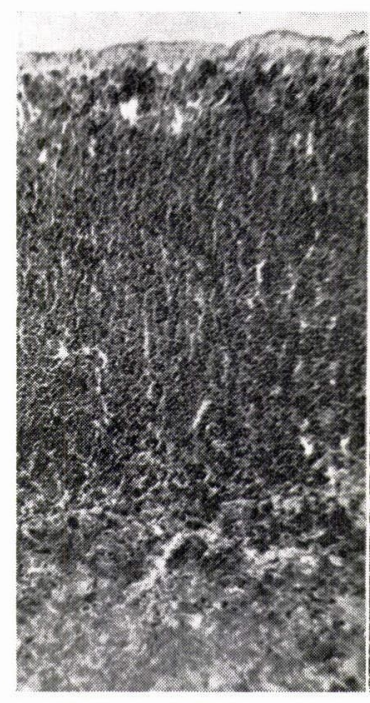

図 $4 \mathrm{a}$ 対照群 6 力月 Sudan III染色 脂質は球状帯に少なく, 束状帯に多いが，網状帯 ではやや少ない。

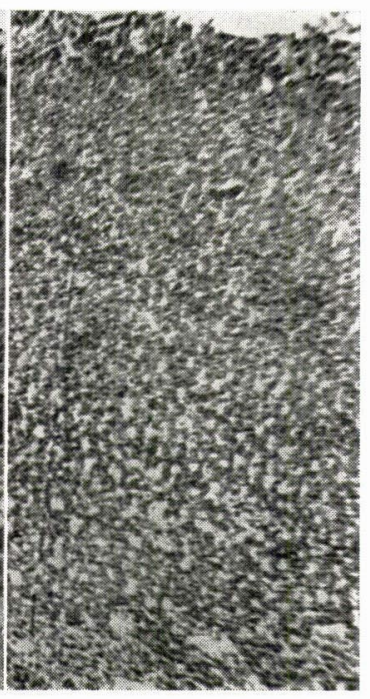

図 4 b Ch.T.O. 群 6 力月 Sudan III染色 脂質は球状帯から網状帯迄 の全層にわたり殆んど認め られない。
mT.O. 群：Ch.mT.O. 群と同様，脂質ならび にコレステリンは実験期間 4.5 カ月以降では減少 を示し， 6 力月では球状帯にのみ脂質がわずかに 残つているに過ぎなかつた。

c 腎

1. 対照群

全実験期間を通じて肉眼的にもまた組織学的に もなんら異常は認められなかつた。

\section{2. 実験群}

Ch.Cs.O. 群と Ch.Cs.mT.O. 群 : 実験期間 4.5 カ月以降になると, 肉眼的にやや黄色味をおび, 組織学的には尿細管上皮に脂肪滴の沈着が極めて 軽度に認められた。

Ch.mT.O. 群と mT.O. 群 : 実験期間 4.5 力月 迄は対照群との間に特に明らかな差は見られなか つたが， 6 カ月では肉眼的に腫脹が明らかで，黄 色の斑点状色調を呈するようになり, 組織学的に は主部尿細管上皮に著しい脂肪沈着が認められ， 
いわゆるリポイドネフローゼの所見を示していた (図 5 )。

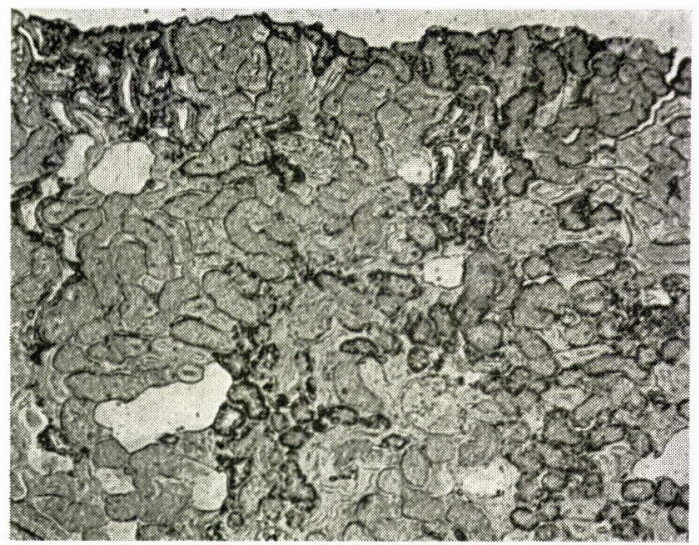

図 5 Ch.mT.O. 群 6 力月 Sudan III染色 主部尿細管上皮に著しい脂肪沈着が見られ，いわ ゆるリポイドネフローゼの所見を呈している。

\section{d 甲状腺}

\section{1. 対照群}

肉眼的にもまた組織学的にも全実験期間を通じ てほぼ同様な所見を呈していた。すなわち，腺実 質は円形, 卵円形あるいは多角形の大小いろいろ の濾胞からなつており, 濾胞の内壁は一層の低立 方状上皮で扔执れ，内腔は PAS 陽性のコロイ ドによつて充されていた（図6a)。

\section{2. 実験群}

Ch.Cs.O. 群：肉眼的には全実験期閒を通じて 対照群とほぼ同様な所見を呈していたが, 組織学 的には対照群よりも濾胞の大きさがやや小さく, 内腔の PAS 陽性コロイドが幾分減少していた。

Ch.Cs.mT.O., Ch.mT.O., mT.O. 各 3 群：肉 眼的にはいずれも肥大が著明であり，実験期間 3 カ月の重量比で対照群の 5 ないし 6 倍となつてい た。しかし, 肥大は実験期間 4.5 あるいは 6 力月 のものでも，3 カ月のものとほぼ同程度であつ た。組織学的にはいずれも腺実質の著しい増殖, 腺上皮の腫大とくに高さの増加, 濾胞の著しい縮 小と PAS 陽性コロイドの消失など高度の過形成 様所見呈していた。な祘，各 3 群の間には特に 明らかな変化の差は見られなかのた（図 $6 \mathrm{~b}$ )。

e 心ならびに血管

心：実験期間 6 力月の Ch.mT.O., mT.O. 雨 群の心筋には局在性の脂肪沈着が認められた。

大動脈：㿤験期閒 6 力月の Ch.Cs.mT.O. 群の 外膜には, Sudan III で染め出される多量の脂質 の沈着が見られた。明らかなアテローム性変化お よび硬化性病変は各群とも見られず, 中膜のコレ ステリン量も対照との間に明らかな差は認められ なかつた。

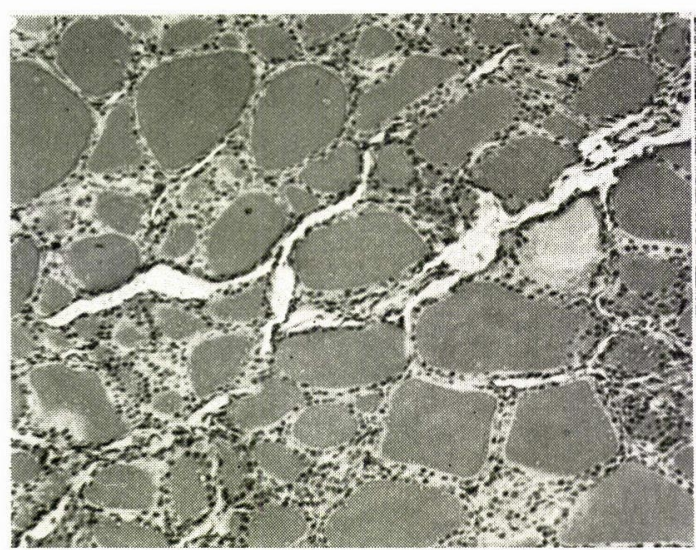

図 $6 \mathrm{a}$ 対照群 6 力月 PAS 染色 円形, 卵円形あるいは多角形の大小いろいろの濾 胞から成り，濾胞の内壁は一層の低立方状上皮で おおわれ，内腔は PAS 陽性のコロイドにより充 されている。

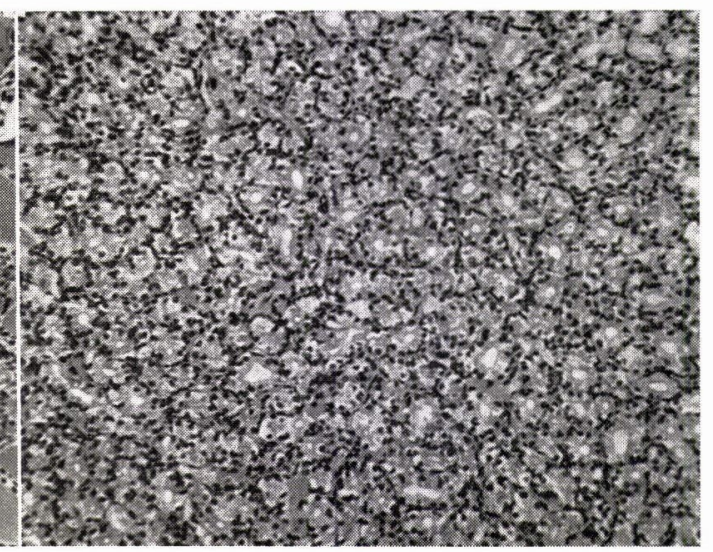

図 $6 \mathrm{~b}$ mT. O. 群 6 力月 PAS 染色 腺実質の著しい増殖, 腺上皮の腫大, 濾胞の著し い縮小と PAS 陽性コロイドの消失が認められる。 
腎, 肺動脈: Ch.Cs.O., Ch.Cs.mT.O., Ch.mT. O. 各 3 群の一部の例では内膜の肥厚, 内弾性板 の断裂が見られたが，明らかなアテローム性硬化 症の発症は認められなかつた。

小動脈: アテローム性変化および硬化性病変は 全く見られなかつた。

なお, 臟器の脈管内の血液成分は, Ch.Cs.mT.O, Ch.Cs.O., Ch.mT.O. 各 3 群では血中コレステリ ン值の高低に応じて Sudan III で赤色に染め出さ れた。

\section{D 歯周組織}

1. 対照群

1) 咬合側

肉眼的ならびにX線所見： 実験期間が長くな るにつれて，歯牙の咬耗が明らかになり，臨床歯 冠および解剖歯冠は大きさをやや減じていた。 $\mathrm{M}_{1} \mathrm{M}_{2} \mathrm{M}_{3}$ の咬合面を結ぶ線はいずれもほぼ直線 をなしていた。また，実験期間 4.5 力月以降のも のでは $\mathrm{M}_{1} \mathrm{M}_{2}$ 間に軽度の歯隙がしばしば見られ た。歯肉の污染や明らかな炎症性病変は殆んど認 められなかつた。根間中隔下部の歯槽骨は実験期 間 6 力月以降ではX線透過性をやや増していた。

組織学的所見(図 7,8)：歯肉の退縮は 実験期 間 9 力月迄では各乳頭部とも殆んど認めれなかつ た。一般に歯肉固有層には軽度の炎性症細胞浸潤 が見られ，実験期間 6 力月以降になると歯間乳頭 部では細胞浸潤がやや増していた。しかし，いず れの場合も炎症性変化は歯肉固有層のみにとどま つており，深部に波及しているものは全くなかつ た。

歯根膜隙の広さや Sharpey 線維の機能配列は 各部ともほぼ一定に保たれており，実験期間によ る差は特に明らかではなかつた。

歯槽骨縁の高さは実験期間 6 力月迄は各部とも ほぼ同様にエナメル・セメント境のやや下方に位 置していたが， 7.5 カ月以降になると $\mathrm{M}_{1}$ 近心部 で他部よりもやや低くなつていた。また，根間中 隔部骨頂には全実験期間を通じて骨改造が見られ た。各歯槽側壁には歯牙の生理的な動きにより生 ずる一定の骨吸收像と添加像が全実験期間を通じ
て認められた。すなわち， $M_{1}$ 近心根歯槽壁近心 側の歯頸部附近と各歯根歯槽壁遠心側の根尖部附 近から根中央部あるいは根分岐部附近にかけては 不規則な骨吸収像が見られ， $M_{1}$ 近心根歯槽壁近 心側の根尖部附近では不規則な骨吸収像と添加像 の両者が見られ， $\mathrm{M}_{1}$ 近心根を除く各歯根歯槽壁 近心側の根尖部附近から根中央部あるいは根分岐 部附近にかけては骨添加像が見られた。なお，実 験期間 6 力月以降の根尖部附近から根間中隔下部 にかけての歯槽骨には骨多孔性変化が軽度に認め られた。

有細胞セメント質は各歯根根尖部附近に根尖を 包むように認められ，実験期間が長くなるにつれ てやや増殖を示していた。増殖は $M_{1}$ 近心根と $\mathrm{M}_{3}$ 遠心根の近心側で明らかであつた。線維性セ メント質は歯頸部附近や根分岐部など根尖部附近 以外の部に認められ，実験期間が長くなるにつれ て, 一般に $M_{1}$ 近心と $M_{3}$ 遠心側のほかの部分で はやや肥厚を示していた。肥厚は歯間部の歯間水 平勒帯に接続する場所で明らかであつた。また， $\mathrm{M}_{1}$ 近心柬頸部附近の線維性セメント質には不規 則な吸収像が見られ，しばしば象牙質迄吸収が及 んでいた。

2) 対合歯抜去側

肉眼的ならびにX線所見 : 実験期間が長くなる につれて，歯牙の挺出に伴う歯肉の退縮が歯間乳 頭部以外の場所では明らかになり，臨床歯冠は大 きさを増していた。挺出は $\mathrm{M}_{2}$ で高度であり， $\mathrm{M}_{1} \mathrm{M}_{2} \mathrm{M}_{3}$ の咬合面を結ぶ線は $\mathrm{M}_{2}$ を頂点とする 孤線をなしていた。また, 実験期間 3 カ月ですで に $\mathrm{M}_{1} \mathrm{M}_{2}$ 間には歯隙が見られ，実験期間が長く なると歯隙はさらに明らかになつていた。歯肉の 污染や明らかな炎症性病変は殆んど認められなか つた。また，各歯根は実験期間が長くなるにつれ て太く且つやや長くなつていた。根尖部附近およ び根間中隔下部の歯槽骨は実験期間 6 力月以降で はX線透過性をやや増していた。

組織学的所見 (図 9,10): $M_{1}$ 近心と $M_{3}$ 遠心 部では歯牙の挺出に伴い歯肉の退縮が見られ，実 験期間が長くなるにつれて，歯肉の退縮は明らか 


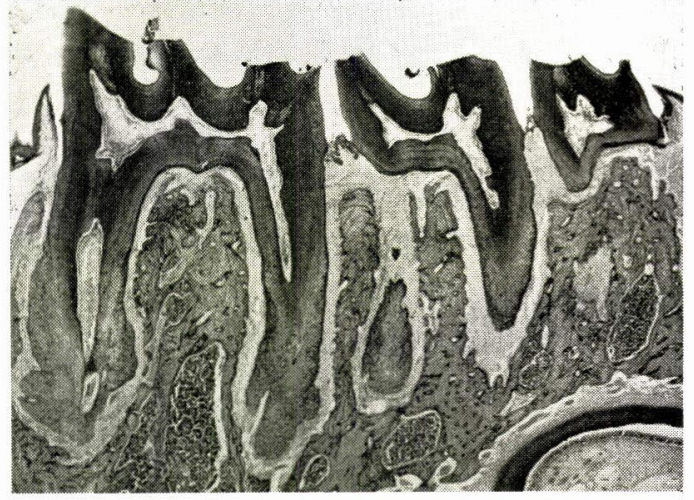

図 7 対照群 6 力月咬合側 $\mathrm{HE}$ 染色 炎症性細胞浸潤は歯間乳頭部でやや明らかで あるが，深部には波及していない。

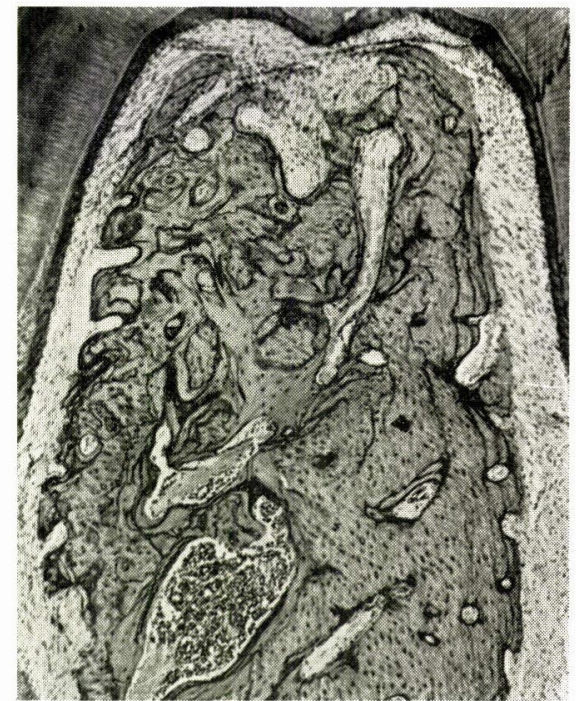

図 8 対照群 6 力月咬合側

$\mathrm{M}_{1}$ 根間中隔部 $\mathrm{HE}$ 染色 骨多孔性変化は殆んど見られない。

であつた。しかしながら，歯間乳頭部では歯肉の 退縮は実験期間 9 カ月迄では殆んど認められなか つた。歯肉固有層には極めて軽度の炎症性細胞浸 潤が見られ，実験期間が長くなるにつれて細胞浸 潤はやや増していた。しかし，いずれの場合も炎 症性変化は歯肉固有層のみにとどまつて抢り，深 部に波及しているものは全くなかつた。

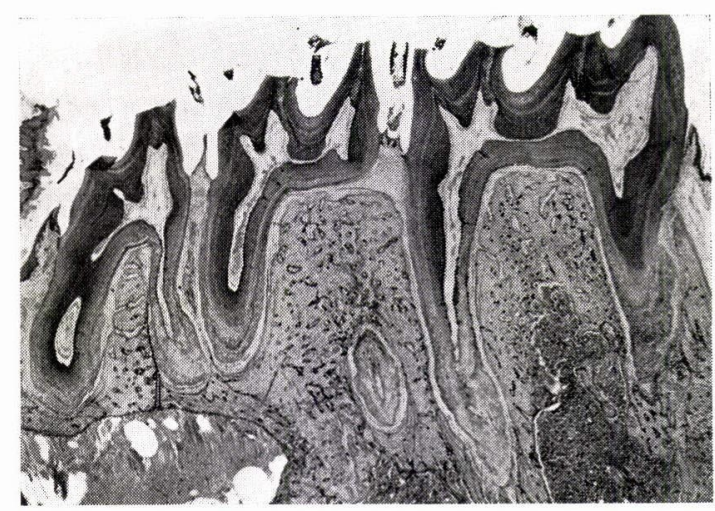

図 9 刘照群 6 力月対合歯抜去側 $\mathrm{HE}$ 染色 炎症性細胞浸潤が軽度に認められるが，いずれも 歯肉固有層のみにとどまつている。

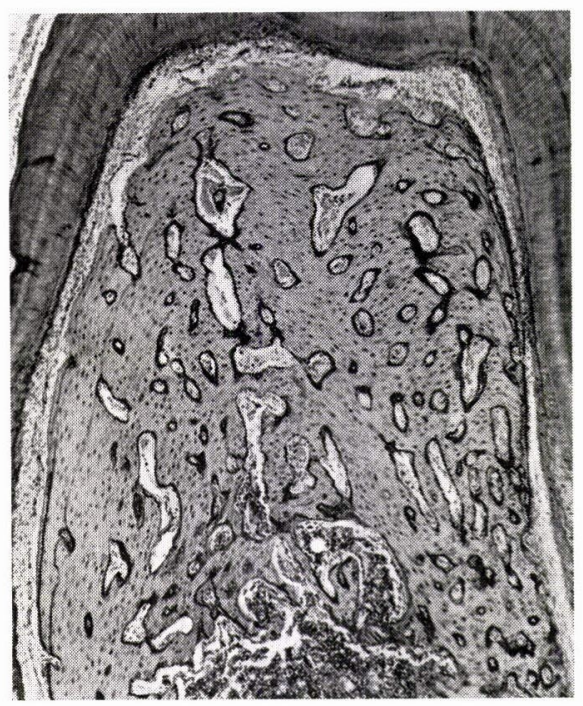

図 10 対照群 6 力月対合歯抜去側 $M_{1}$ 根間中隔部 $\mathrm{HE}$ 染色

骨多孔性変化は殆んど見られない。

歯根膜隙は全実験期間を通じて咬合側よりも明 らかに狭くなつて抢り, Sharpey 線維は萎縮が明 らかで，機能配列を殆んど㕵失していた。しか し，実験期間 7.5 力月以降では，歯頸部附近ある いは根分岐部の一部で Sharpey 線維の数がやや 増し, 機能配列を軽度ながら再現している例があ つた。 
歯槽骨縁の高さは $M_{1}$ 近心部では歯肉の退縮に 伴い低くなつているが，その他の部では骨頂に骨 添加が見られ, 実験期間 4.5 力月迄は歯槽骨縁の高 さは咬合側とほぼ同様にエナメル・セメント境の やや下方に位置していた。実験期間 6 カ月以降に なると骨頂では骨添加の減弱と骨吸収が見られ, 歯槽骨縁の高さはいずれも低くなつていた。また, 根間中隔部骨頂には実験期間 6 力月迄は骨新生が 著明に認められたが， 7.5 力月以降になると一部 に骨改造が見られるようになつた。歯槽側壁には 歯牙の生理的な動きにより生ずる骨吸収像と添加 像が咬合側とほぼ同様の場所に認められたが，一 般に咬合側ほど明らかではなかつた。なお，実験 期間 6 力月以降の根尖下部および根尖部附近から 根間中隔下部にかけての歯槽骨には骨多孔性変化 が軽度に認められた。

有細胞七メント質は実験期閒が長くなるにつれ て咬合側よりもさらに明らかな増殖を示してお り，増殖は歯頸部方向と根尖部一明らかであっ た。線維性セメント質も実験期間が長くなるにつ れて, $M_{1}$ 近心と $M_{3}$ 遠心側を除く部で肥厚を示 しており，特に歯間部において明らかであつた。 また， $M_{1}$ 近心歯頸部附近の線維性セメント質に は不規則な吸収像がしばしば見られた。

\section{2. 実験群}

1）咬合側

肉眼的ならでにX線所見：Ch.Cs.O., Ch.Cs. mT.O., Ch.mT.O 各 3 群は 対照群に比較すると 全般的に歯肉の污染が明らかであり, Ch.Cs.O 群 の各実験期間のものと Ch.Cs.mT.O., Ch.mT.O 両群の実験期間 4.5 力月以降のものの歯間部には 明らかな炎症性病変と歯肉の退縮が認められた。 また, Ch.Cs.O., Ch.Cs.mT.O. 両群の実験期間 4.5 力月以降と Ch.mT.O. 群の 6 力月の歯榑骨は X線透過性を対照群よりも増していた。なお, mT.O. 群注全般的に対照群とほぼ同様な所見を 呈していた。

組織学的所見 :

Ch.Cs.O. 群：歯肉では対照群に比較すると全 般的に炎症性変化が増強していた。炎症の増悪は
特に歯間部で明らかであり，実験期間 3 力月では 歯肉の退縮, 歯間水平勒带の破壞, 病的歯肉囊の 形成を伴う歯槽骨および歯根膜への炎症の波及が 見られたものがあつた（図 11)。炎症性病変は実 験期間が長くなるにつれてさらに明らかになり， 実験期間 6 力月以降では根尖部附近や根分岐部迄 波及していた（図 12）。しかし， $M_{1}$ 近心と $M_{3}$ 遠 心部では炎症性変化は比較的軽度で, 歯肉の退縮 や病的歯肉囊の形成は殆んど見られなかつた。

歯根膜隙や Sharpey 線維の機能配列は, 炎症 が波及してない場所では全般的に対照群との間に 明らかな差がなかつた。しかし，全身衰弱の高度 な一部の例では歯根膜隙は対照群よりもやや広く なつていた（図14）。

歯槽骨では対照群に比較すると骨吸収機転の増 強と骨形成機転の減弱が明らかであつた。実験期 間 4.5 カ月以降では根尖部附近から根間中隔部に かけての骨多孔性変化が明らかで, 変化は骨頂部 附近迄及んでいた（図 13）。なお，全身衰弱の高 度な一部の例では骨形成機転が殆んど停止すると ともに骨吸収機転もやや減弱し，一部の骨細胞の

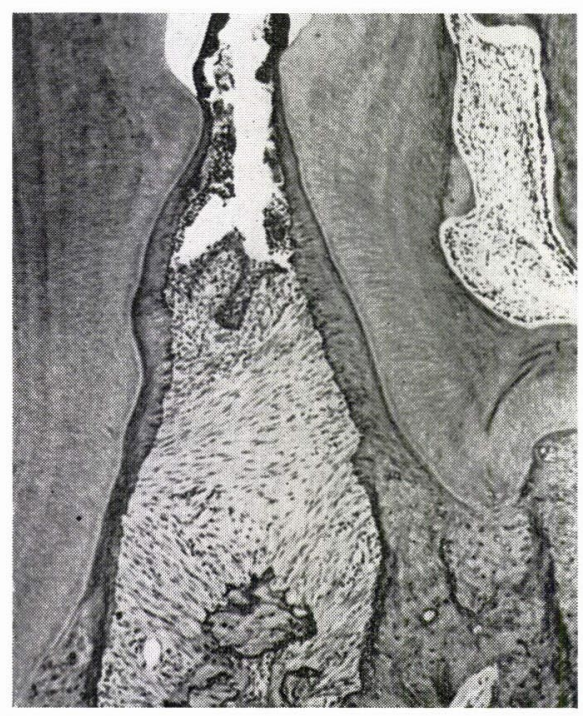

図 11 Ch.Cs. O. 群 3 力月咬合測 HE 染色 炎症性変化が明らかで, 病的歯肉囊の形成, 歯 肉の退縮, 一部歯間水平勒帯の破壊が認めら れ，歯間歯槽骨骨頂には炎症による骨吸収像 が見られる。 


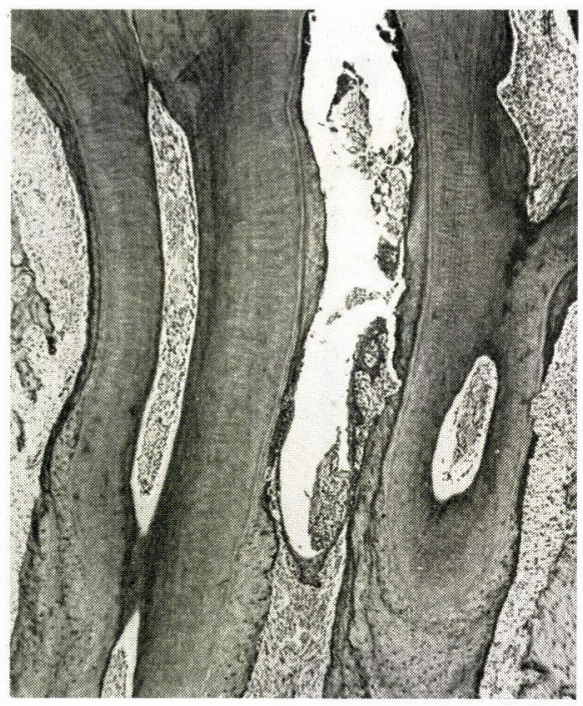

図 12 Ch.Cs. O. 群 6 力月咬合側 HE 染色 炎症性変化が著明で，歯肉の退縮，歯間水平 䩲带の破壊が認められ，炎症は根尖部および 根分岐部方向に向い波及している。

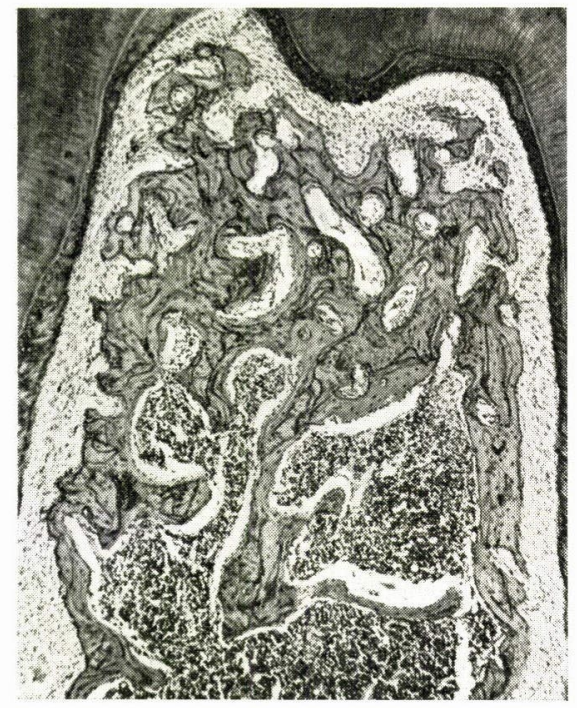

図 13 Ch.Cs. O. 群 6 力月咬合側 $\mathrm{M}_{1}$ 根間中隔部 $\mathrm{HE}$ 染色

骨多孔性変化が著明であり，根間中隔部骨頂 にも及んでいる。

変性壊死や骨髄線維化を伴う骨多孔性変化を示し ていた（図 14）。

有細胞セメント質の増殖や線維性セメント質の

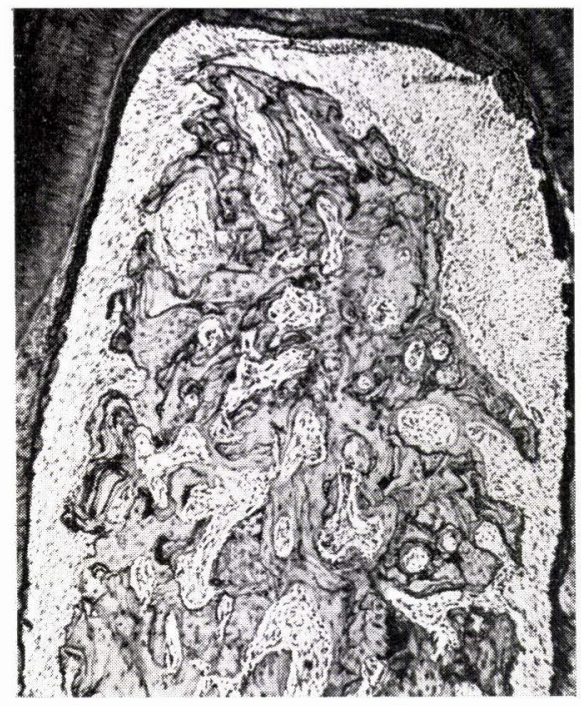

図 14 Ch.Cs.O. 群 6 力月咬合側 $M_{1}$ 根間中隔部 $\mathrm{HE}$ 染色

骨髄の線維化を伴う骨多孔性変化か明らかで, 歯根膜隙はやや挔大している。

なお，図の右上の歯根膜隙の拉大は炎症の波 及による。

肥厚は対照群よりも明らかであり，且つ不規則な 形をとつていた。

Ch.Cs.mT.O. 群 : 歯肉では対照群に比較する と炎症性変化が増強していた。炎症の増悪は歯間 部で明らかであり, 実験期間 4.5 力月以降では歯 肉の退縮, 歯間水平䩲帯の破壊が見られ, 炎症が 歯槽骨や歯根膜一波及したものがあつた（図 15）。

歯根膜隙や Sharpey 線維の機能配列は, 炎症 が波及していない場所では実験期間 4.5 力月迄は 対照群との間に特に明らかな差がなかつた。しか し, 実験期間 6 力月では Sharpey 線維 は軽度の 萎縮を示しており, 根分岐部歯根膜に変性の認的 られたものがあつた（図 16）。

歯槽骨は対照群に比較すると, 全般的に骨吸収 機転の増強と骨形成機転の減弱が著明であつた。 根尖部附近から根間中隔部にかけての骨多孔性变 化は甚だしく著明であり, 実験期間 6 カ月では骨 頂部にもおよんでいたほか, 骨髄では脂肪組織が 増加していた（図 16）。

有細胞セメント質の増殖は対照群との間に特に 


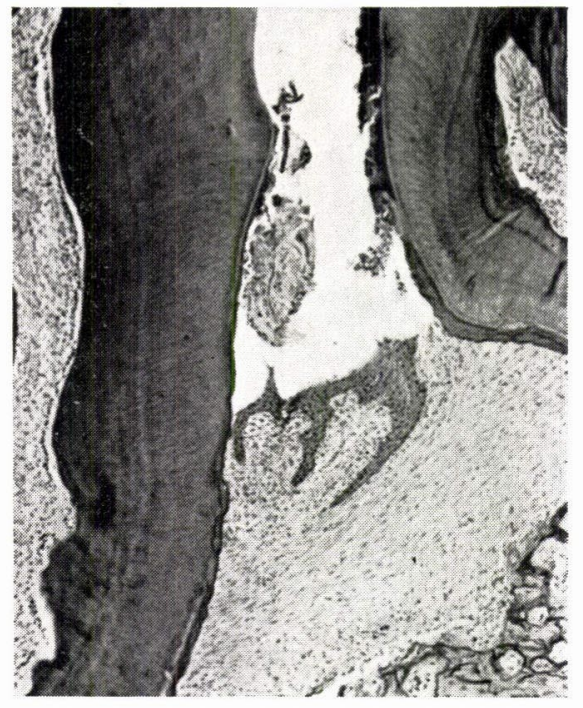

図 15 Ch.Cs.mT.O. 群 6 力月咬合側

$\mathrm{HE}$ 染色

资症性変化が明からで, 歯肉の退縮や歯間水 平靶帯の破壊が認められ，歯槽骨には炎症に よる骨吸収像が見られる。

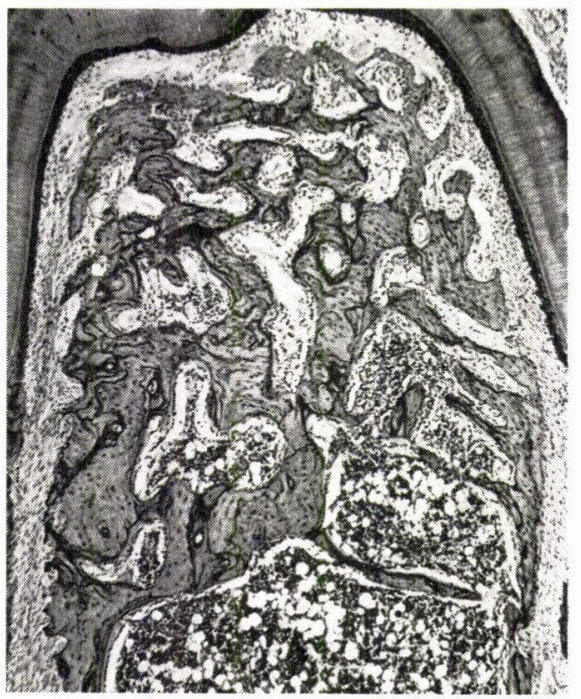

図 16 Ch.Cs.mT.O. 群 6 力月咬合側 $M_{1}$ 根間中隔部 $\mathrm{HE}$ 染色 骨多孔性変化が著明であり, 骨全体に及び, 骨髄では脂肪組織の浸潤が明らかである。 根分岐部の歯根膜には Sharpey 線維の変性 が認められる。
明らかな差がなかつたが，線維性セメント質の肥 厚はやや明らかで且つ不規則な形をとつていた。

Ch.mT.O. 群： 歯肉では対照群に比較すると 炎症性変化がやや増強しており, 実験期間 4.5 力 月以降の歯間部では歯肉の退縮, 歯間水平勒帯の 破壊を伴つているのが見られた。

歯根膜隙や Sharpey 線維の 機能配列は対照群 とほぼ同程度であつた。

歯槽骨では実験期間 6 力月になると対照群より も骨吸収機転が増強しており, 骨多孔性変化は根 尖部附近から根間中隔骨頂部附近にまでおよんで いた (図 17)。

有細胞セメント質の増殖，線維性セメント質の 肥厚は対照群との間に特に明らかな差がなかつ た。

mT.O. 群 : 歯肉, 歯根膜, 歯槽骨, セメント 質のいずれも対照群とほぼ同様な所見を呈してい た（図 18）。

2）対合歯抜去側

肉眼的ならびにX線所見：歯牙の挺出およびそ れに伴う歯肉 の退縮は Ch.Cs.O. 群の実験期間

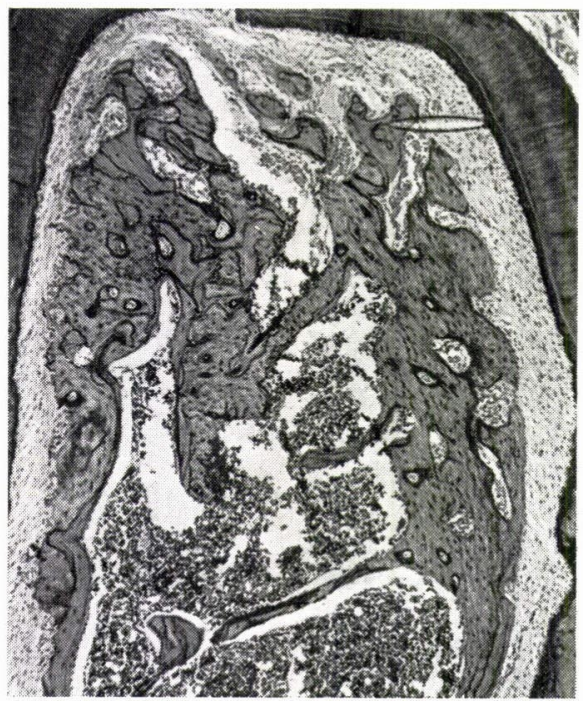

図 17 Ch.mT.O. 群 6 力月咬合側 $\mathrm{M}_{1}$ 根間中隔部 $\mathrm{HE}$ 染色 骨多孔性変化が明らかで，根間中隔部骨頂付 近に及んでいる。 


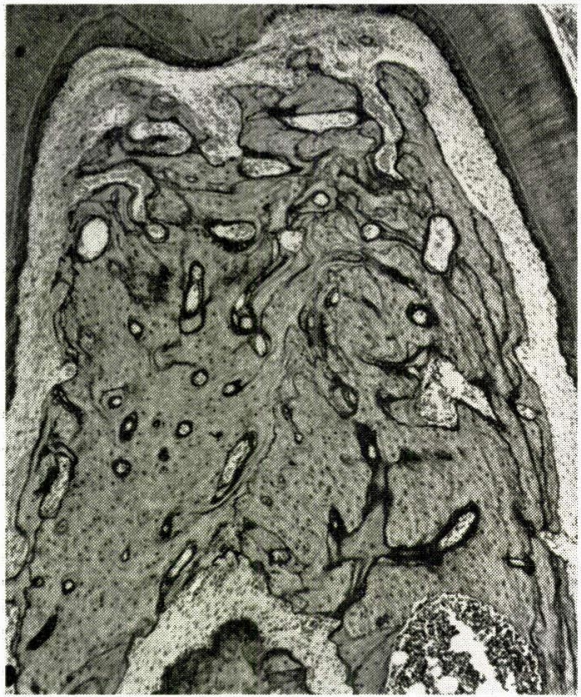

図 $18 \mathrm{mT}$. O. 群 6 力月咬合側

$\mathrm{M}_{1}$ 根間中隔部 $\mathrm{HE}$ 染色

対照群と同様に骨多孔性変化は殆んど認めら れない。

6 力月以降では対照群よりも明らかであつた。 Ch.Cs.O., Ch.Cs.mT., Ch.mT.O. 各 3 群は対照 群に比較すると歯肉の污染が明らかであり， Ch.Cs.O. 群の各実験期間のものと Ch.Cs.mT.O. 群の実験期間 4.5 力月以降のものの歯間部には明 らかな次症性病変と歯肉の退縮が認められた。ま た, Ch.Cs.O., Ch.Cs.mT.O. 両群の実験期間 4.5 カ月以降と Ch.mT.O. 群の 6 力月の歯槽骨はX 線透過性を対照群よりも増していた。なお， mT.O. 群拄全般的に対照群とほぼ同様な所見を 呈していた。

組織学的所見 :

Ch.Cs.O. 群：歯肉では対照群に比較すると炎 症性変化が増強していた。炎症の増悪は各実験期 間のものとも歯間乳頭部で明らかで，歯肉の退 縮, 病的歯肉囊の形成, 歯間水平鞖带の破懐を伴 心，炎症性変化が歯槽骨および歯根膜人波及して いるのが見られた（図 $19 ， 20$ )。 $M_{1}$ 近心と $M_{3}$ 遠 心部における歯肉の退縮は実験期間 4.5 力月以降 では対照群よりも明らかであつた。

歯根膜隙の狭窄やSharpey 線維の萎縮と機能 配列の培失の程度は, 炎症が波及していない場所

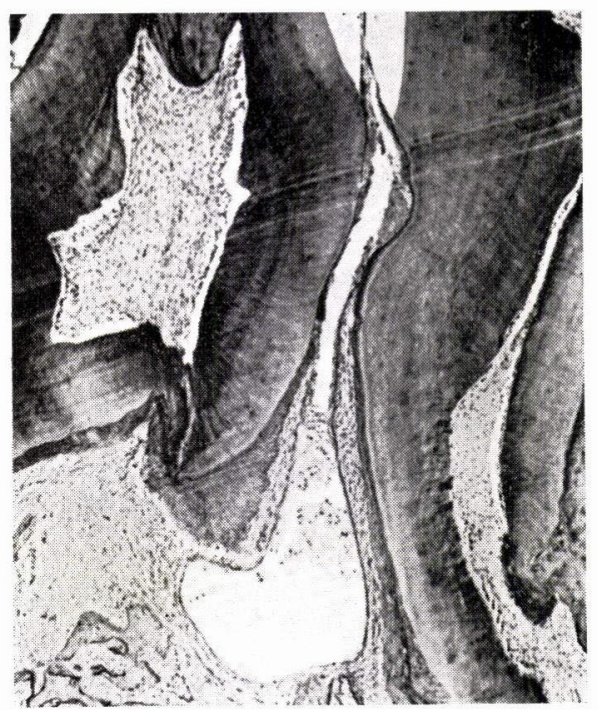

図 19 Ch.Cs.O. 群 3 力月対合歯抜去側

HE 染色

炎症性変化が明らかで，歯肉の退縮，歯間水 平䩲帯の破壊を伴いながら歯槽骨や歯根膜な ど深部に炎症が波及している。

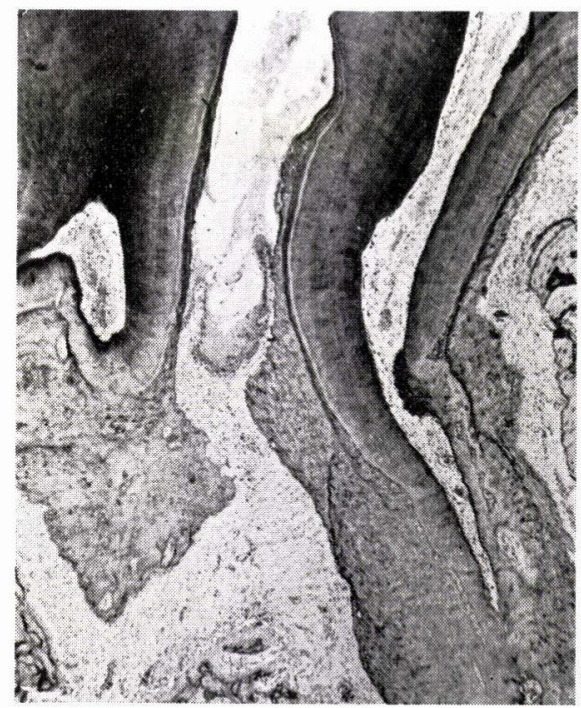

図 20 Ch.Cs. O. 群 6 力月対合歯抜去側

$\mathrm{HE}$ 染色

炎症性変化が明らかで，歯肉の退縮や歯間水 平靶帯の破壊が認められる。歯槽骨の炎症に は吸収部には新たな骨新生が始まつている。

では対照群抜去側とほぼ同様であつた。しかし， 全身衰弱の高度な一部の例では歯根膜隙が対照群 
よりやや広くなつているものがあつた（図 22）。

歯槽骨縁つ高さは，炎症が歯槽骨まで波及して いない $M_{1}$ 近心と $M_{3}$ 遠心においても対照群より やや低くなつていた。歯槽骨では対照群抜去側よ りも全般的に骨吸収機転の増強と骨形成機転の減 弱が明らかであり，实験期間 4.5 力月以降では根 尖部附近から根間中隔部にかけての骨多孔性変化 が骨頂の骨新生部附近迄及んでいた（図 21）。な お，全身衰弱の高度な一部の例では骨形成機転 が殆んど停止するとともに骨吸収機転もやや減弱 し, 一部の骨細胞の変性壊死, 骨䯣の線維化を伴 ら骨多孔性変化を示していた（図 22）。

有細胞セメント質の増殖や線維性セメント質の 肥厚は対照群抜去側よりも明らかであり, 且つ不 規則な形をとつていた。

Ch.Cs.mT.O. 群： 歯肉では対照群に比較する と炎症性変化が増強していた。炎症の増悪は特に 歯間乳頭部で明らかであり, 実験期間 4.5 カ月で は歯肉の退縮, 病的歯肉囊の形成を伴つており, さらに 6 力月では歯間水平䩲帯の破壊を伴いなが ら炎症性変化が歯槽骨や歯根膜へ波及しているの

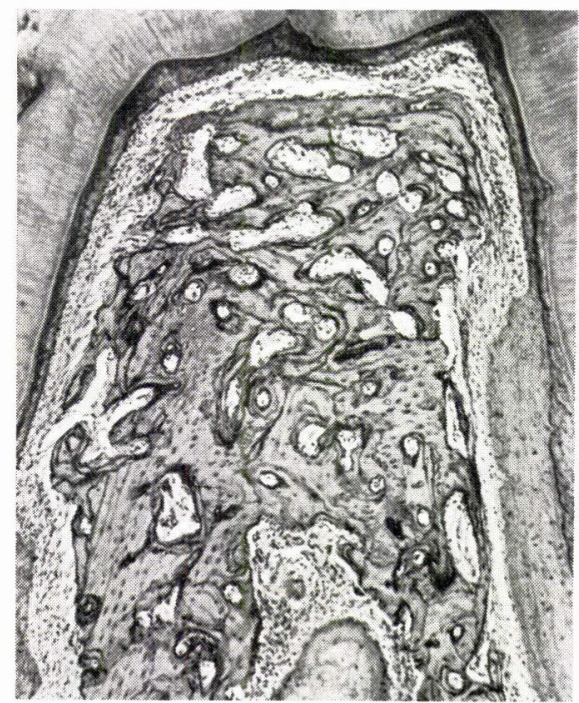

図 21 Ch.Cs.O. 群 6 力月対合歯抜去側 $\mathrm{M}_{1}$ 根間中隔部 $\mathrm{HE}$ 染色

骨多孔性変化が明らかで, 一部骨細胞の壊死, 骨髄の一部線維化が認められる。（栄養障害 のやや高度な例）

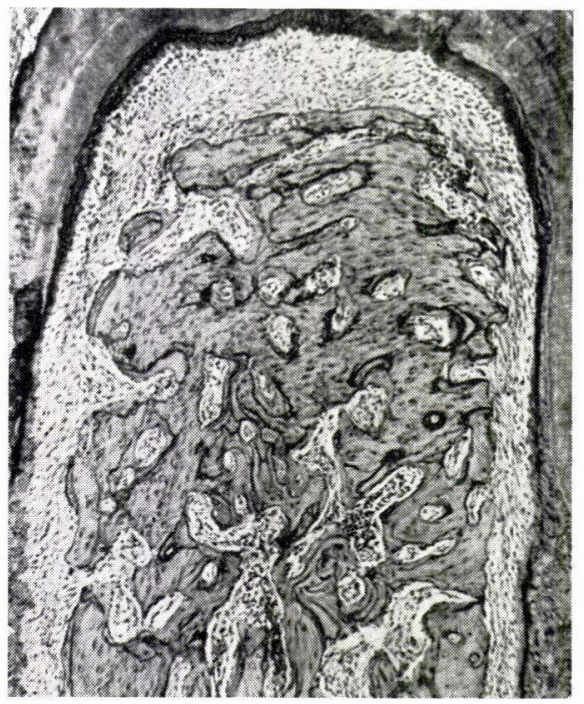

図 22 Ch.Cs.O. 群 4.5 力月対合歯抜去側 $M_{1}$ 根間中隔部 $\mathrm{HE}$ 染色

骨の萎縮性変化が明らかであり, 骨髄の線維 化，一部骨細胞の変性壊死を伴う骨多孔性変 化が涩められる。歯根膜隙の拡大が著明であ る。

\section{が見られた（湌 23）。}

歯根膜隙の狭窄や Sharpey 線維の萎縮と機能 配列の岢失の程度は実験期間 4.5 力月迄は対照群 抜去側とほぼ同様であつたが, 6 カ月では Sharpey 線維の萎縮がさらに著しくなつていた。

歯槽骨では対照群抜去側よりも骨吸収機転の増 強と骨形成機転の減弱が著明であり, 骨多孔性変 化が高度で，実験期間 6 力月では骨頂の骨新生部 におよんでいたほか，骨髄では脂肪組織がやや増 加していた (図 24)。

有細胞セメント質の増殖は対照群抜去側との間 に明らかな差がなかつたが，線維性セメント質は 歯間部で肥厚がやや明らかで，且つ不規則な形を とつていた。

Ch.mT.O. 群：歯肉の炎症性変化は対照群よ りもやや明らかであつたが，歯槽骨や歯根膜など へ波及した例は実験期間 6 カ月迄ではなかつた。

歯槽骨では実験期間 6 力月になると骨吸収機転 が対照群抜去側よりも増強しており, 根尖部附近 


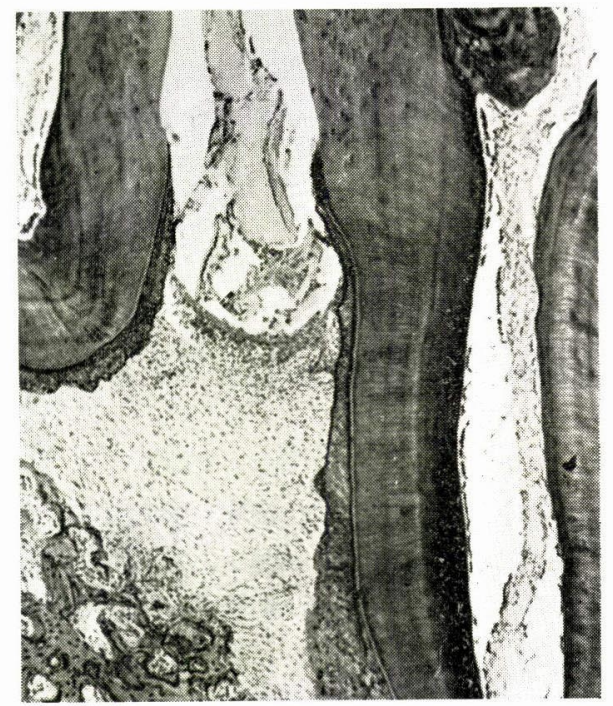

図 23 Ch.Cs.mT.O. 群 6 力月対合歯抜去側 HE 染色 炎症性変化が明らかで，歯肉の退縮，歯間水 平靭帯の破壊が認められ歯槽骨には炎症によ る骨吸収像が見られる。

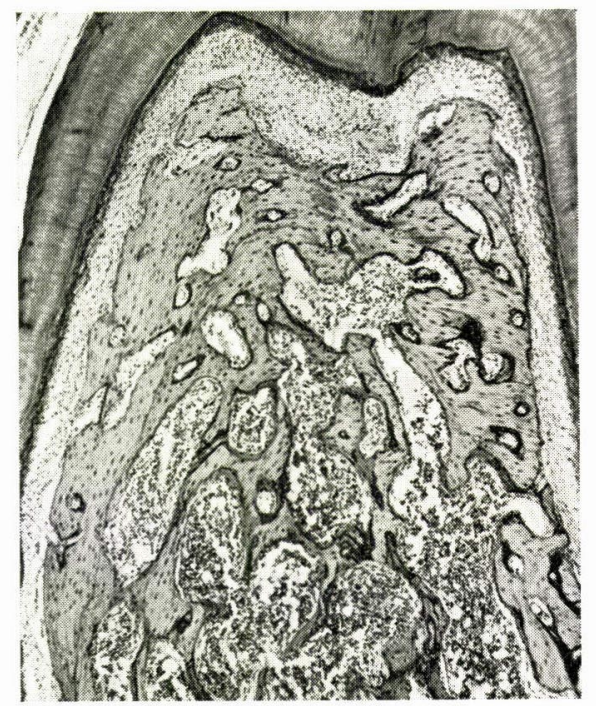

図 24 Ch.Cs.mT.O. 群 6 力月対合歯抜去側 $\mathrm{M}_{1}$ 根間中隔部 $\mathrm{HE}$ 染色

骨多孔性変化が明らかで骨頂部付近にまで及 んでいる。

から根間中隔部にかけての骨多孔性変化が明らか になつた。(図 25)。

有細胞七メント質の増殖, 線維性セメント質の

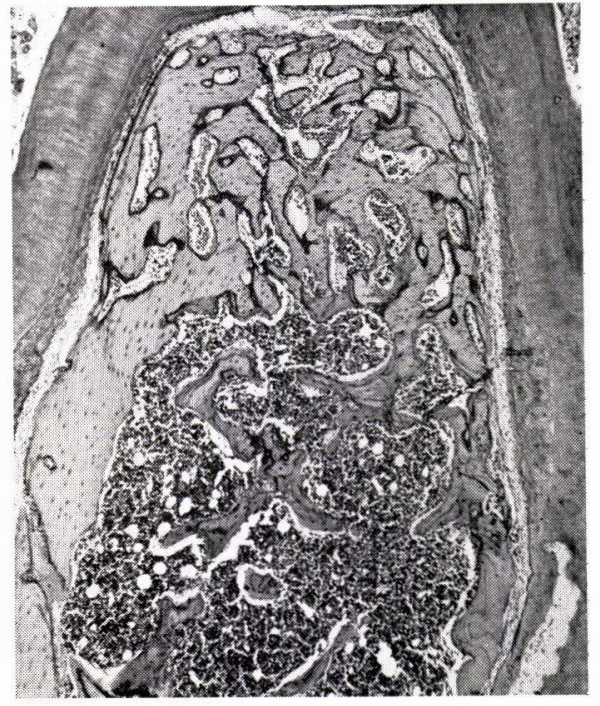

図 25 Ch.mT.O. 群 6 力月対合歯抜去側 $M_{1}$ 根間中隔部 $\mathrm{HE}$ 染色

骨多孔性変化が明らかで骨頂部付近にまで及 んでいる。

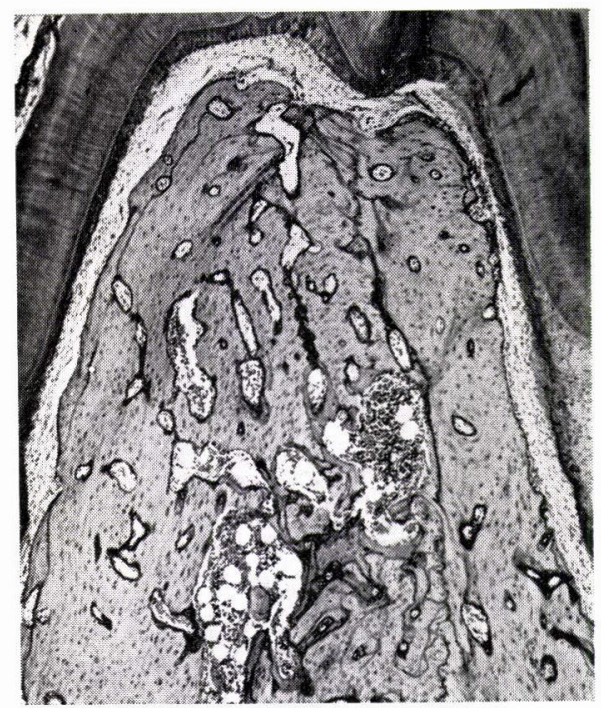

図 26 mT.O. 群 6 力月対合歯抜去側 $\mathrm{M}_{1}$ 根間中隔部 $\mathrm{HE}$ 染色 対照群と同様に骨多孔性変化は殆んど認めら れない。

肥厚は対照群抜去側との間に明らかな差がなかつ た。

mT.O. 群： 歯肉, 歯根膜, 歯槽骨, セメント 
質のいずれも対照群抜去側とほぼ同様な所見を呈 していた（図 26）。

\section{E 下肢骨}

1. 対照群

実験期間が長くなるにつれて，骨端部軟骨層の 幅が幾分狭くなり，肥大層軟骨細胞の萎縮と予備 石灰化層の骨芽細胞の減少がやや明らかになつて いたが，実験期間 6 力月迄では原始骨梁掞よび二 次骨梁の形成も良好であつた（図 $27 \mathrm{a}$ )。実験期間 7.5 力月以降では原始骨梁の形成がやや減弱する とともに二次骨梁の数もやや減少しており, 骨髄 では脂肪組織がやや増加していた。

\section{2. 実験群}

Ch.Cs.O. 群：対照群に比較すると，実験期間 3 力月では肥大層軟骨細胞の萎縮がやや明らかで あつたが，その他に著変は認められなかつた。実 験期間 4.5 力月になると, 肥大層軟骨細胞の萎縮 はさらに明らかになり，石灰化軟骨基質の吸収が 昂進し, 骨芽細胞の減少が見られ, 原始骨梁の形
成が減弱するとともに二次骨梁の数も幾分減少し ていた。実験期間 6 力月以降では, 原始骨梁の形 成はさらに減弱し, 二次骨梁の数の減少も明らか になつた(図 $27 \mathrm{~b})$ 。なお，全身衰弱の高度な一部 の例では, 骨端部軟骨層の幅は著しく薄くなり, 軟骨細胞の萎縮や配列不正が明らかであつた。こ のような例では原始骨梁の形成は著しく阻害さ れ, 二次骨梁は数の減少と細少化が著明であつ た。

Ch.Cs.mT.O. 群 : 対照群に比較すると, 実験 期間 3 力月では肥大層軟骨細胞の萎縮がやや明ら かで, 原始骨梁の形成は減弱し, 特に数の減少が 著明で, 石灰化軟骨基質の吸収昂進々骨芽細胞の 減少が見られた。これらの変化は実験期間 4.5 力 月では 3 カ月のものとほぼ同程度であつたが， 6 カ月になると一痺明らかになり, 二次骨梁の著し い数の減少が見られたほか, 骨髄では脂肪組織の 浸潤が高度であつた (図 $27 \mathrm{c}$ )。

Ch.mT.O. 群：対照群に比較すると, 実験期

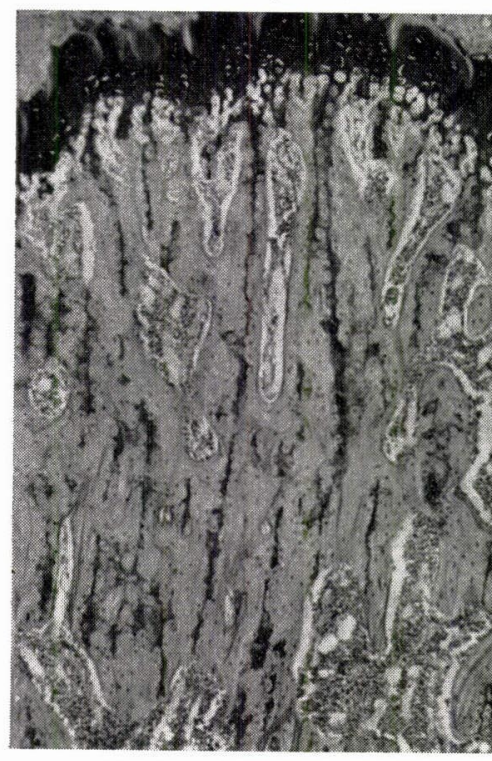

図 $27 \mathrm{a}$ 対照群 6 力月 大腿骨骨端部

原始骨梁, 二次骨梁とも形成は 良好である。

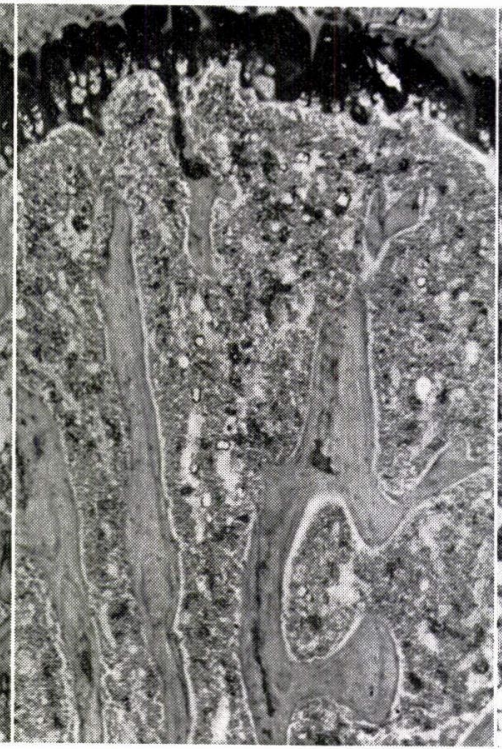

図 27 b Ch.Cs. O. 群 6 力月 大腿骨骨端部

原始骨梁の形成は減弱しており，二 次骨梁の数も少なく, 石死化軟骨基 質の吸収昂進が見られる。

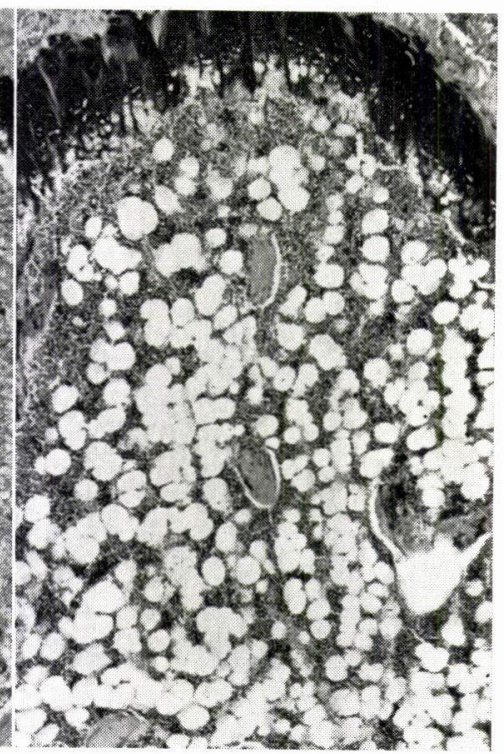

図 27 c Ch.Cs.mT.O. 群 6 力月 大腿骨骨端部

原始骨梁, 二次骨梁とも形成が減 弱しており, 骨梁の数は極端に減 少している。骨髄では脂肪組織の 浸潤が著明である。 
間 3 力月では特に差がなかつたが，4.5 カ月にな ると肥大層軟骨細胞の萎縮，石灰化軟骨基質の吸 收昂進, 骨芽細胞の減少がやや明らかになり，原 始骨梁の形成はやや減弱していた。これらの変化 は実験期間 6 力月ではさらに明らかになり, 二次 骨梁の数の減少が見られ, 骨髄では脂肪組織の浸 潤が高度であつた。

mT.O. 群 : 対照群に比較すると, 実験期間 4.5 カ月では差はなかつたが， 6 力月では肥大層軟骨 細胞の萎縮と石灰化軟骨基質の吸収帠進がやや明 らかで, 原始骨梁の形成が幾分減弱していたほか, 骨髄では脂肪組織の浸潤が明らかであつた。

\section{IV 総括ならびに考案}

一般的所見 :

体重の増加程度を対照群に比較すると, Ch.mT. O., mT.O. 両群ではやや低く, Ch.Cs.O., Ch.Cs. mT.O. 両群ではさらに低くなつていたが，いず れも実験開始以来体重が減少することはなかつ た。また，摂取飼料量は対照群よりもCh.mT.O., mT.O. 両群で約 4 g, Ch.Cs.O., Ch.Cs.mT.O. 両 群で約 $6 \mathrm{~g} 1$ 匹 1 日当りで少なくなつていた。従 来，コレステリン投与は体重の増加傾向に特に影 響を与えないこと年を,17,34), 幼弱ラットの場合に は増加率がやや低いこと ${ }^{54,57,58)}$, 胆汁酸投与 ${ }^{18,44)}$, 抗甲状腺剂投与 ${ }^{34,38}$ が体重の増加を低くするこ と, コレステリン, 胆汁酸, 抗甲状腺剂を含む合成 食投与では体重が減少すること的などが記されて いる。今回の実験ではコレステリン, 抗甲状腺㧩, 大豆油そのものは体重の増加程度に特に影響を与 えず，胆汁酸と捸取飼料量の減少が体重の増加を 抑制する因子として働いたと考えられる。

血中コレステリン值 :

血中コレステリン值の上昇は Ch.Cs.mT.O. 群 で最も著明で, 以下 Ch.Cs.O., Ch.mT.O., mT.O. 群の順であり, 実験期間 6 力月の平均で Ch.Cs. mT.O. 群は対照群の約 4 倍, Ch.Cs.O. 群は約 3 倍, Ch.mT.O. 群は約 2 倍, mT.O. 群は約 1.2 倍となつていた。ラットの場合コレステリンのみ の投与では血中コレスデリン值は正常の 1.5 倍以

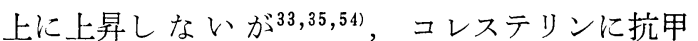

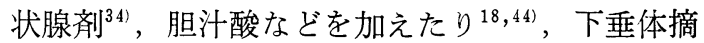
出 ${ }^{45,59)}$ を行なうとさらに上昇することが報告され ており,コレステリン, 胆汁酸, 抗甲状腺剤などを 含む合成食で飼育すると 15-20 倍の上昇を示すこ とが報告されている ${ }^{19)}$ 。胆汁酸が血中コレステリ ン值を上昇させる機序についてはコレステリン $\rightarrow$ 胆汁酸変化の抑制 ${ }^{22}$, 外来コレステリン吸収の促 進 ${ }^{19)}$ ，血中のコレステリン移動の抑制 ${ }^{13)}$ などが考 えられており，抗甲状腺剤投与および甲状腺機能 減退が血中コレステリン值を上昇させる機序につ いては甲状腺ホルモン抑制により血中のコレステ

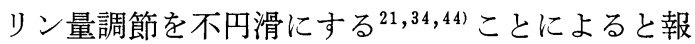
告されているが，著者の場合も同様の機序による ものと思われる。

肝：対照群では全実験期間を通じて Sudan III で染め出される脂質および 偏光顕微鏡で検出さ れるコレステリンは殆んどないが, 実験群では脂 質とくにコレステリン浸潤による脂肪化が見られ た。脂肪化は Ch.Cs.mT.O. 群で最も高度で, 以下 Ch.Cs.O., Ch.mT.O., mT.O. 群の順であり, 血 中コレステリン值の上昇にほぼ平行して認められ た。一方，全身衰弱の高度な例に見られた中心脂 肪変性部にはコレステリン結晶は検出されなかつ た。コレステリン投与による肝の脂肪化について は Anitschowら (1913) ${ }^{2)}$ 以来多くの報告 ${ }^{11,14,17,43,65)}$ が見られ，いずれもコレステリン浸潤を主とした 軽度ないし中等度の周辺脂肪化を認めている。ま た,コレステリンに胆汁酸 ${ }^{18,44}$, 大豆油 ${ }^{58)}$ などを加 えると脂肪化は明らかになり, Woods ら $(1964)^{62)}$ はコレステリン，胆汁酸，抗甲状腺剤を含む合成 食飼育ラットに高度の脂肪肝が発症したことを報 告している。今回の実験でも脂肪肝の発症が見ら れ，特に Ch.Cs.mT.O., Ch.Cs.O. 両群などコレ ステリンのほか, 胆汁酸や抗甲状腺剤を投与した 群で脂肪化が高度であつた。このことから，胆汁 酸, 抗甲状腺剤などは高コレステリン血症を発症 させるのと同様に肝の脂肪化に対しても促進的に 作用したと思われる。

副腎皮質： 脂質およびコレステリンは Ch.Cs. 
O. 群では対照群よりも著しく増加を示したが， Ch.Cs.mT.O., Ch.mT.O., mT.O. 各群ではむし ろ減少する傾向を示しており，特に実験期間 6 力 月の Ch.mT.O., mT.O. 両群では脂質は殆んど 消失していた。コレステリン投与により副腎皮質 の脂質の増加することは Bernick ら(1961) ${ }^{8)} に よ$ つて報告されており，本実験でもコレステリン， 胆汁酸, 大豆油を投与した群では脂質の増加が認 められた。しかし，コレステリン投与の有無にか かわらず，抗甲状腺剤を投与した例では脂質が減 少しており，特に胆汁酸を投与せずに抗甲状腺剂 を投与した例では脂質は殆んど消失していた。ラ ットにおけるこの種の実験で副腎皮質の脂質が消 失したといら報告は見られないが，本実験の結果 から高コレステリン血症, 脂肪肝が必ずしも皮質 の脂質の増減に影響するとは限らず，脂質の消失 に直接影響を与えたのは抗甲状腺剤投与による甲 状腺機能障害, とくに Thyroxine の大幅な消費

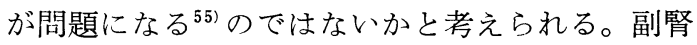
皮質の脂質に関してはこのほかストレスによる影 響や，下垂体，副腎皮質ホルモンとの関連を考慮 する必要があると思われる。

腎：コレステリン投与により尿細管上皮に軽度 の脂質とくにコレステリン沈着が見られること ${ }^{9)}$ は報告されており，本実験でも高コレステリン血 症，脂肪肝などの明らかな Ch.Cs.O., Ch.Cs.mT. O. 両群では脂肪滴の軽度の沈着が見られたが, 一方血中コレステリン值の上昇や肝の脂肪化が特 に著明でない Ch.mT.O., mT.O. 群 6 カ月では 明らかなリポイドネフローゼが認められた。こ の種の実験で Thomas ら(1959) ${ }^{56)}$ ， Gresham ら $(1960)^{30)}$, Woods ら $(1964)^{62)}$ は腎の梗塞を報告し ているが，明らかなリポイドネフローゼを発症し たといら報告は見られない。著者の場合, リポイ ドネフローゼを発症した例では副腎皮質の脂質の 消失を伴つているのが特徴であつたが，このこと から，リポイドネフローゼは必ずしも高コレステ リン血症や脂肪肝など全身性の脂質代謝異常に関 連して発症するとは限らず，副腎皮質の脂質の消 失や甲状腺機能障害がなんらかの形で関連してい
るのではないかと考えられる。

甲状腺：コレステリン投与により甲状腺が軽度 の過形成像を示すこと ${ }^{8,10)}$ は報告されている。ラ ットの場合コレステリンのみの投与で血中コレス テリン值が殆んど上昇しないのは，甲状腺ホルモ ン合成が活発になり，正常より多量に合成された 甲状腺ホルモンが血中の脂質やコレステリン量を 調節することによる ${ }^{8,10,12)}$ とされており，過形成 像はコレステリンを投与した場合，甲状腺機能昂 進を起すべく下垂体前葉の甲状腺刺激ホルモンが 分泌するために生ずると考えられている。外来の コレステリンに対する甲状腺の形態学的所見は動 物種によつて異なつて抢り， Bernick ら (1962) ${ }^{10}$ はコレステリン投与における血中コレステリン值 が動物種によつて異なるのは甲状腺機能にも関連 するのではないかと報告している。ラットにおい て著者および戸枝, 山本 $(1963)^{58)}$ がコレステリ ンと大豆油を投与した場合には甲状腺は形態学 的に変化が認められず，血中コレステリン值の軽 度の上昇が見られたが，このことからも甲状腺の 形態学的変化と血中コレステリン值にはなんらか の関連があるのではないかと思われる。本実験 で Ch.Cs.O. 群における過形成像が Bernick ら $\left(1961^{8)} ， 1962^{10)}\right)$ の報告ほど明らかでなかつたの は，コレステリンに胆汁酸，大豆油を加えた投与 のため高コレステリン血症が生じたことによると 推測される。

一方，抗甲状腺剤投与による甲状腺の高度の過 形成像は Mitchell(1950) ${ }^{38)}$ により報告されている が，著者の実験でも Ch.Cs.mT.O., Ch.m'T.O., mT.O. の 3 群には同様な所見が認められた。こ の場合はコレステリン投与における甲状腺機能昂 進とは異なり，抗甲状腺剤投与による甲状腺ホル モン合成の抑制, すなわち甲状腺機能減退が生じ たために，下垂体前葉の甲状腺刺激ホルモンが多 量に分泌され，その結果肥大，腺実質の増殖など 腺腫様の形をとつたものであろう ${ }^{64)}$ 。

心筋との関連については Thomas ら (1959) ${ }^{56)}$ により，コレステリン，胆汁酸，抗甲状腺剤を含 む合成食で飼育したラットに心筋梗塞が認められ 
ているが, 著者の場合では Ch.mT.O., mT.O. 両 群に局在性の脂肪沈着が認められ，このような例 ではリポイドネフローゼ, 副腎皮質の脂質の消失 を伴つていることが多かつた。

動脈硬化症については Fillios ら $(1956)^{19)}$, Wilgram ら (1959) ${ }^{60)}$ により報告されており，著者 の場合では腎，肺動脈に内膜の肥厚や内弾性板の 断裂が見られたほか, 大動脈外膜に脂肪沈着が認 められた。

歯周組織 :

歯肉では対照群においても通常固有層に軽度の 炎症性細胞浸潤が認められ，特に咬合側の歯間乳 頭部で他の部分よりやや明らかであつたが，対照 群の場合炎症性変化が歯槽骨や歯根膜など深部に 波及することは全くなかつた。実験群においては 一般に炎症性変化の増悪が見られ, Ch.Cs.O 群で 最も高度で, 以下 Ch.Cs.mT.O., Ch.mT.O. 群の 順であつたが, mT.O. 群では対照群と殆んど差 がなかつた。Ch.Cs.O., Ch.Cs.mT.O., Ch.m'T.O. 各 3 群では炎症が歯槽骨や歯根膜なビ深部に波及 しており，いわゆる辺縁性歯周炎を発症している のが見られた。また，炎症の増悪は一般に高コ レステリン血症, 脂肪肝の明らかな例に見られた が，必ずしも血中コレステリン值の上昇や肝の脂 肪化の程度に平行するとは限らなかつた。咬合側 と対合歯抜去側との間には炎症性病変の程度につ いて甚だしい差は見られなかつたが，一般に歯間 乳頭部歯肉では咬合側の方が炎症の増覀はやや明 らかであり, $\mathrm{M}_{1}$ 近心と $\mathrm{M}_{3}$ 遠心部では対合歯抜 去側の方が明らかであつた。なお，対合歯抜去側 歯間部では歯牙の挺出に伴い歯䄚骨は相対的に退 縮するが，歯肉は退縮しないために，一旦炎症が 増悪しても歯槽骨や歯根膜部に波及寸ることは咬 合側同部に比較すると少なかつた。炎症性病変は 一般に実験期間が長くなるにつれてさらに明らか になつていたが，必ずしも進行性の過程をとると は限らず，歯槽骨に炎症による骨吸収が見られる にもかかわらず，炎症性細胞浸潤は単に歯肉上皮 下結合組織にのみ軽度にとどまつている例もしば しば認められた。
歯根膜は対照群の場合，咬合側では各実験期間 のものともほぼ一定の幅に保たれており，Sharpey 線維は機能配列を示していたが，対合歯抜 去側では歯根膜隙は狭窄しており, Sharpey 線維 は萎縮と機能配列の哂失を示していた。実験群で は咬合側でも，また対合歯抜去側でも炎症が波及 している場所を除けば対照群との間に特に明らか な差はなかつたが, Ch.Cs.mT.O. 群 6 カ月の一 部の例で対照群より Sharpey 線維の萎縮が明ら かで，咬合側根分岐部で変性を示している例があ つた。なお，全身衰弱の高度な一部の例では骨形 成機転が阻害された結果歯根膜隙が対照群より広 くなつているのが見られた。

歯槽骨では対照群においても実験期間が長いも のでは根尖部附近から根間中隔下部にかけて骨髄 腔の桩大が見られ，生理的に骨多孔性変化を示し ていた。骨多孔性変化は根尖部附近や根尖下部で は対合歯抜去側の方が明らかであつた。また，各 歯槽側壁には歯牙の生理的な動きにより生ずる骨 添加像と吸収像が見られたほか，咬合側根間中隔 部骨頂には骨改造像が，対合歯抜去側根間中隔部 骨頂には著明な骨新生像が認められた。実験群で は骨吸収機転の増強と骨形成機転の減弱が明らか であり，骨多孔性変化が対照群よりも増強してい た。骨多孔性変化の増強は Ch.Cs.mT.O. 群で最 も高度で, 以下 Ch.Cs.O., Ch.mT.O. 群の順で あつたが， mT.O. 群では対照群との差が明らか ではなかつた。これらの変化は血中のコレステリ ン值の上昇, 肝の脂肪化の程度に平行して現われ たが, リポイドネフローゼ，心筋脂肪沈着，副腎 皮質脂質の消失などの変化には特に関連性を示さ なかつた。咬合側と対合歯抜去側とを比較する と，対合歯抜去側における骨多孔性変化は一般に 根尖部附近や根間中隔下部でやや高度であつた が，生理的に骨新生の旺盛な根間中隔部骨頂や歯 槽側壁骨添加部では軽度であり，且つ発現も遅れ ていた。骨髄の脂肪組織の浸潤は Ch.Cs.mT.O. 群 6 力月の例に明らかであつたが，その他の群で は殆んど見られなかつた。

セメント質は対照群においても実験期間が長く 
なるにつれてやや増殖あるいは肥厚を示し，その 程度は対合歯抜去側で高度であつた。実験群にお いては線維性セメント質, 有細胞セメント質の両 者とも対照群同側よりも肥厚あるいは増殖がやや 明らかで，且つ不規則な形をとつていた。しかし ながらこれらの変化は，高コレステリン血症，脂 肪肝, リポイド腎症, 心筋脂肪沈着とはとくに関 連性を示さず，歯根膜線維の性状，局所の炎症に よつて左右されていた。

辺縁性歯周疾患と新陳代謝障害との関連につい てとくに脂質代謝の方面からなされた研究はきわ めて少ない。始め Mitchell(1950) ${ }^{38)}$ は抗甲状腺剂 を投与したハムスターの歯周組織を観察し、歯周 疾患と基礎代謝および血中コレステリン值との間 に特に関連がないことを述べたが，著者および戸 枝, 山本 $(1963)^{58)}$, はコレステリンと大豆油投与 の幼弱ラットに血中コレステリン值の軽度の上昇 と肝の周辺脂肪化および歯肉炎の増悪を認めた。 また，今回の実験では高コレステリン血症や脂肪 肝の明らかな例に歯肉の炎症性変化の増悪, 歯槽 骨の多孔性変化の増強, 歯根膜線維の配列不正 および変性, セメント質の不規則な肥厚および増 殖などが認められた。

歯肉の炎症性変化の増悪に関しては一般に考え られているように局所的因子によつて影響される 点が大きく, 全身的因子としての脂質代謝異常が どのような機転で関与しているかを正確に把握す ることは困難と思われるが，なんらかの形で感染 に対する局所の抵抗力を減弱させたのではないか と考えられる。コレステリンの大量な負荷が歯周 組織の脂質を通して直接組織に影響を与え, 感染 に対する抵抗力を減弱させ歯肉炎の増悪をきたす ということも全くないとはいえないであろうが， それを推定せさる所見は殆んど得られないように 思われる。とするとやはり，今回の実験によつて 招来される変化は一般に脂質代謝の中心的藏器之 見做されている肝の脂質代謝が先ず激しく粯乱さ れるというところから始まると想像される。その 結果脂肪肝が生じたのであろらが, 肝における脂 質代謝異常は当然さらに糖代謝, 蛋白質代謝など
の異常を惹起し，それらは拡大的に悪循環を重ね ながら肝機能の著しい低下を招来するであろう。 例えば糖代謝では，高脂肪食が肝のグルコキナー ゼの活性を低下させるという報告 ${ }^{66)}$ もるから， この場合にもこんなことが糖代謝異常のきつかけ をつくるのかもしれない。また過剩のコレステリ ン投与がアセチル CoA の貯溜をきたし ${ }^{3,63)}$,さら に摂取飼料の減少などもからんで相対的なビタミ ン不足を伴つてアチドーシスを起す可能性も考え られる。一方肝機能の低下は肝でつくられる血清 アルブミンを始めとする諸種蛋白(酵素を含めて) や補酵素などの生産能を減弱せしめるであろう。

こうなると全身の諸組織は当然栄養障害的な要素 をうけるであろうし，それは抗体生産のような生 体防衛の機構にも波及するかも知れない。このよ うなことから本実験に見られた肝の脂質代謝異常 が二次的あるいは間接的に組織の感染に対する抵 抗力を減弱させるよう働いているのではないかと 想像される。

今回の実験においてこれらのことがどの程度に 起つているかを解明するにはさらにいくつかの生 化学的な検索を重ねなければならないが，多少に 拘らずこれらの変化が起る方向に動いていること は否定出来ない。また, 副腎皮質, 甲状腺, 腎な どの変化も関連がないとはいえないが，具体的に それを解明する手がかりはまだつかめていないよ うに思われる。しかし, 甲状腺機能異常のみの影 響では今回の実験で歯肉炎の増悪はとくに認めら れなかつた。

炎症の増悪は場所的には咬合側では主に歯間部 で見られ， $M_{1}$ 近心と $M_{3}$ 遠心部では殆んど見ら れず,対合歯抜去側では各部とも見られたが, 歯間 部では咬合側ほど明らかではなかつた。一般にラ ットにおいては Belting ら(1953) 7 が述べている ように咬合機能が営まれている場合, $M_{1}$ 近心や $\mathrm{M}_{3}$ 遠心部に比較して歯間部の方が炎症性細胞浸 潤はやや明らかであるが，本実験においても同様 な所見が認められた。また，対合歯を喪失した歯 牙の歯周組織についての研究 ${ }^{1,29,46,47)}$ は多く行な われており，一般に歯肉の退縮が見られることが 
記されているが，著者の場合歯間部では歯肉の退 縮は殆んど見られず，炎症性細胞浸潤も咬合側同 部よりむしろ轻度であつた。ラットの歯間乳頭部 では, 自浄作用の減退よりも咬合による食物圧 入, 機械的刺激の要素が大きいため, 咬合側の方 が炎症性細胞浸潤がやや強いのではないかと思わ れる。

以上のように対照群における炎症性細胞浸潤は 歯肉の部位によりやや異なつているが, 実験群に おける炎症の強い部位は一般に生理的にも炎症性 細胞浸潤が明らかな場所であることが多かつた。 これらの結果から見でも，全身的因子はそれのみ で辺縁性歯周炎も惹起し得るものではなく，あく までも二次的あるいは間接的に炎症の増悪に促進 的に作用するものであるという見解は極めて妥当 な考えであると思われる。

歯根膜と代謝疾患との関連については，小守 $(1964)^{36)}$ がアロキサン糖尿病ラットの対合歯を喪 失した歯根膜で Sharpey 線維の萎縮が増強する ことを報告している。本実験でも高コレステリン 血症, 脂肪肝の明らかな例の一部に Sharpey 線 維の萎縮と変性を認めたが, 対合歯抜去による変 化, 炎症の波及や歯槽骨の萎縮による変化など局 所的因子による影響が強く, 脂質代謝との関連を 明らかにすることは出来なかつた。

脂質代謝と骨多孔性変化との関連についての報 告はないが, 今回の実験では高コレステリン血症, 肝の脂肪化の程度に平行して骨多孔性变化の増強 が認められた。従来, 実験的にラットにおいて骨 多孔症を発症せしめた研究は Glickman (1947) ${ }^{26)}$, Chawla 抢よび Glickman $(1951)^{15)}$, Sandler ら $(1955)^{49)}$, Goldman $(1955)^{28)}$, 藤井 $(1960)^{25)}$, 小 守(1964) ${ }^{36)}$ らの代謝疾患における場合のほかスト レスを与えた場合 ${ }^{31}$ などが報告されている。

著者の実験では，抗甲状腺剤投与による甲状腺 機能異常それ自身は歯槽骨に影響を与えたとは思 えず，またリポイドネフローゼ，心筋脂肪沈着， 副腎皮質脂質の消失を生じた例においても骨多孔 性変化は特に強くなかつた。一方, 高コレステリ ン血症や肝の脂肪化が著明な例では骨多孔性変化
の増強が認められ，この場合骨吸収機転の増強と 骨形成機転の減弱が明らかで, 骨䯣腔の扡大, 海 綿骨梁の細小化, 緻密骨部における Havers 管, Volkman 小管の桩大などが見られた。これらの変 化は一般に生理的に見られる老人性骨多孔症と類 似していたが，骨吸収機転の増強が骨形成機転の 減弱よりも明らかである点がやや異なつていた。 高コレステリン血症や脂肪肝の明らかな例に見ら れた骨多孔性変化の発現機序については, 脂質代 謝異常とくに肝の脂質代謝異常とそれによる糖質 代謝異常や蛋白質代謝異常の惹起などの要素のほ か, 甲状腺機能異常, 薬物投与によるストレスなど の要素も加わつた結果生じたものと推測される。 しかし，これらの関連についてはそれを解明する 手がかりが明らかでなく, さらに生化学的な検索 や組織化学的な観察を待たねばならない。なお, 全身衰弱の高度な例に見られた変化は骨形成機転 の阻害が骨吸収機転の増強よりも明らかなことが 特徵であり，一般に蛋白欠乏食やアロキサン糖尿 病における骨変化と類似していたが，この場合の 変化には高度の飢餓的要素が関与しているのでは ないかと考えられる。

咬合側と対合歯抜去側について一般に対照群の 場合は明らかな差がなかつたにも拘らず，実験群 では明らかに咬合側の方が骨多孔性変化は高度 であつた。これは咬合により受ける機械的な刺 激, すなわち機能的要請が強いこと, また根間中 隔部骨頂や歯槽側壁における骨新生が対合歯抜去 側ほど著しくないことなどによると思われる。

骨髄の脂肪組織浸潤は Ch.Cs.mT.O. 群 6 力月 に見られ，脂質代謝異常の結果として生じたもの と思われるが，一方抗甲状腺剤を投与した例の下 肢骨骨髄で脂肪組織の浸潤が明らかだつたことか ら甲状腺機能異常もなんらかのかたちで関与して いるのではないかと考えられる。

セメント質形成に及ぼす全身的因子として，人 体に抢いては Paget 骨病, リウマチ性熱などが 増殖に関して報告されておりり"実験的にはア口 キサン糖尿病ラットで増殖が減弱することが記載 されている ${ }^{36)}$ 。著者の場合, 脂質代謝異常がなん 
らかの影響を与えているのかも知れないが，むし ろ炎症，咬合状態などの局所的因子の方の影響が 大きいと思われる。

下肢骨 :

代謝障害が骨端部の骨梁形成に及ぼす影響につ いては主に蛋白質代謝あるいは糖質代謝の方面か ら研究されてお污2) 36)，脂質代謝の方面からの観 察報告は殁んど見られず，わずかにコレステリン

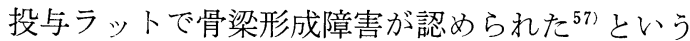
報告があるに過ぎない。

今回の実験で下肢骨骨端部に見られた変化は, 石灰化軟骨基質の吸収昂進，骨芽細胞の減少，原 始骨梁および二次骨梁の減少など骨梁形成障害と 骨髄における脂肪組織の浸潤であつた。

骨梁形成障害は Ch.Cs.mT.O. 群で最も高度 で, 以下 Ch.Cs.O., Ch.mT.O., mT.O. 群の順 であり, 変化の強さは血中コレステリン值の上昇 や肝の脂肪化の程度に平行していた。これらの変 化に見られた特徴は石灰化軟骨基質の吸収昂進と 原始骨梁の数の減少，および骨吸収機転の増強に よる二次骨梁の数の減少であり，骨芽細胞の数の 減少に伴う骨梁形成障害や骨梁改造障害は特に著 しくはなかつた。一方，全身衰弱の高度な例に見 られた変化は上記の変化とやや異なり，軟骨細胞 の萎縮と骨芽細胞の減少が著明であり，石灰化軟 骨基質が突起状の形をとらず，原始骨梁の形成が 全く阻害されており，骨吸収機転の増強よりむし ろ骨形成機転の著しい減弱が特徵であつた。骨端 部骨梁形成に認められた骨吸収機転の増強や骨形 成機転の減弱などは，一般に歯槽骨における骨多 孔性変化の発症機序と類似しており，脂質代謝異 常とくに脂肪肝による肝機能低下により，糖質や 蛋白質の代謝異常を惹起させた結果生じたもので あろうと想像される。

骨髄における脂肪組織の浸潤は血中コレステリ ン值の上昇や肝の脂肪化の程度に必ずしも平行 しておらず，抗甲状腺剤を投与した群で明らかで あつた。このことから本実験に認められた脂肪組 織の浸潤は甲状腺機能異常に関連しているのでは ないかと思われる。

\section{V 要 約}

1. Wistar 系ラットを用い, 左側上顎臼歯抜去 後，次のように実験群を分け薬物投与を胃管によ り行なつた。

1） Ch.Cs.O. 群：コレステリン，コール酸ソ 一ダ, 大豆油

2) Ch.Cs.mT.O. 群 : コレステリン，コール 酸ソーダ，メチルチオウラ シル，大豆油

3） Ch.mT.O. 群 : コレステリン, メチルチオ ウラシル，大豆油

4） mT.O. 群： メチルチオウラシル，大豆 油

実験期間は 6 カ月迄とし，おのおのの血中コレ ステリン値，内臟，下䪽歯周組織，下肢骨骨端部 について観察した。

2. 血中コレステリン值は Ch.Cs.mT.O. 群で 最も上昇し, 以下 Ch.Cs.O., Ch.mT.O., mT.O. 群の順であり，6 カ月では Ch.Cs.mT.O. 群は対 照群の約 4 倍, Ch.Cs.O. 群は約 3 倍, Ch.mT.O. 群は約 2 倍， mT.O. 群は約 1.2 倍の上昇を示し た。

3. 肝の脂肪化およびコレステリン浸潤は Ch.Cs.mT.O. 群で最も高度で，以下 Ch.Cs.O., Ch.mT.O., mT.O. 群の順であり，血中コレステ リン値の上昇とほぼ平行していた。

副腎皮質の脂質ならびにコレステリンは $\mathrm{Ch}$. Cs.O. 群で増加したが，他の 3 群ではむしろ減少 し，とくに Ch.mT.O., mT.O. 群 6 カ月では殆 んど認められず，リポイドネフローゼ，心筋脂肪 沈着を示した例があつた。

メチルチオウラシルを投与した群の甲状腺は肥 大し，実質の増殖，濾胞の縮小，コロイドの消失 など高度の過形成像が認められた。

4. 歯周組織には炎症の増悪, 骨多孔性変化, 歯根膜線維の配列不正，セメント質の不規則な肥 厚が見られたが，mT.O. 群では対照群との差が 明らかではなかつた。

炎症の増悪は一般に高コレステリン血症，脂肪 
肝の明らかな例に見られたが，血中コレステリン 值の上昇，肝の脂肪化の程度に必ずしも平行する とは限らなかつた。咬合側と対合歯抜去側の間に 甚だしい差は見られなかつた。

骨多孔性変化は血中コレステリン值の上昇, 肝 の脂肪化の程度に平行していた。また変化は咬合 側の方が明らかであつた。

歯根膜線維の配列不正，セメント質の不規則な 肥厚は局所的因子によつて影響される点が大であ つた。

5. 下肢骨では石灰化軟骨基質の吸収昂進, 骨 梁の形成障害が見られ，変化は血中コレステリン 值の上昇，肝の脂肪化の程度に平行していた。ま た，骨髄の脂肪浸潤はメチルチオウラシルを投与 した群で明らかであつた。

6. 歯周組織や下肢骨骨端部に見られたこれら の変化は肝の脂質代謝異常における機能低下およ びそれに伴う糖質や蛋白質の代謝異常などによつ て惹起されたものではないかと思われる。

本論文の要旨は第 54 回日本病理学会総会において発 表した。

稿を終るにあたり，終始御懇篤なる御指導と御校閲を 賜つた恩師石川梧朗教授，山本肇助教授に対して心から の感謝を捧げます。また細部にわたる御教示と御校閲 在いただいた荒谷真平教授に深謝いたします。

\section{文献}

1) Anderson, B. G., Smith, A. H., Arnim, S. S. and Orten, A. U. : Changes in molar teeth and their supporting structures of rats following extraction of the upper right first and second molars, Yale J. Biol. \& Med., 9 : 189, 1936.

2) Anitschow, N. and Chalatow, S. : Über experimentelle Cholesterinsteatose und ihre Bedeutung für die Entstehung einiger pathologischer Prozesse, Zentr. allg. Path. u. path. Anat., $24: 1,1913$.

3）新井恒人, 他: TCA Cycle の病理学的研究, TCA Cycle $の$ 代謝障害と実験的動脈硬化症，日病会 誌， $44: 203$, 昭和 30 年.

4) 荒谷真平, 阿南功一, 小林茂三郎 : 医化学入門, 第 3 版, 南山堂, 東京, 昭和 35 年.

5) Auskaps, A., Gupta, O. M. and Shaw, J. H. : Periodontal disease in the rice rat. III. Survey of dietary influences, J. Nutr., 63:325, 1957.

6) Bavetta, L. A. and Bernick, S. : Effects of tryptophan deficiency on the bones and teeth of rats, J. D. Res., $34: 671,1955$.

7) Belting, C. M. Schour, I., Weinmann, J. P. and Shepro, M. J. : Age changes in the periodontal tissues of the rat, molar J. D. Res., 32 : 332, 1953.

8) Bernick, S. and Patek, P. R. : Effect of cholesterol feeding on morphology of selected endocrine glands, Arch. Path., 72 : 89, 1961.

9) Bernick, S. and Patek, P. R. : Effect of cholesterol feeding on rat reticuloendothelial system, Arch. Path., 72 : 78, 1961.

10) Bernick, S., Patek, P. R., Ershoff, B. H. and Wells, A. : Effect of cholesterol feeding on the thyroid gland and vascular structures of the rabbit, guinea pig, hamster and rat, Am. J. Path., $41: 661,1962$.

11) Blatherwick, N. R., Medler, E. M., Bradshaw, P. J., Post, A. L. and Sawyer, S. D. : The dietary production of fatty livers in rats, J. Biol. Chem., 103 : 93, 1933.

12) Boyd, G. S. : Thyroid function, thyroxine analogs, and cholesterol metabolism in rats and rabbits, in "Hormones and atherosclerosis" edited by Pincus, G., New York, Academic Press Inc., 1959, p. 49.

13) Byers, S. O. and Friedman, M. : Production and excretion of cholesterol in animals, VII. Biliary cholesterol: Increment and indicator of hepatic synthesis of cholesterol, Am. J. Physiol., $168: 297,1952$

14) Chanutin, A. and Ludwig, S. : The effect of cholesterol ingestion on tissue lipids of rats, J. Biol. Chem., 102 : 57, 1933.

15) Chawla, T. N. and Glickman, I. : Protein deprivation and the periodontal structures of the albino rat, O.S., O.M. \& O.P., $4: 578,1951$,

16) Cohen, M. M., Shklar, G. and Yerganian, G. : Pulpal and periodontal disease in a strain of Chinese hamsters with hereditary diabetes mellitus, O.S., O.M. \& O.P., $16:$ 104, 1963.

17) Cook, R. P. and McCullagh, G. P. : A comparative study of cholesterol metabolism and its relation to fatty infiltration, with particular reference to experimental cholesterol atheroma, Quart. J. Expr. Physiol., 29 : 283, 1939.

18) Fillios, L. C. and Mann, G. V. : Influence of sulfar amino acid deficiency on cholesterol metabolism, Metabolism, 3:16, 1954.

19) Fillios, L. C., Andrus, S. B., Mann, G. V. and Stare, F. J. : Experimental production of gross 
atherosclerosis in the rat, J. Expr. Med., 104 : 539, 1956.

20) Fisher, L. M., Kagan, E. and Kupfer, H. C. : Blood coagulation chnages in rats fed high fat diets, Circulation Res., 13 : 529, 1963.

21) Fleishmann, W. and Schamcker, H. B. : The relationship between serum cholesterol and total body cholesterol in hyper-hypothyroidism, Bull. Johns Hopkins Hosp., 71 : 175, 1942.

22) Follis, R. H. : Deficiency disease. Springfield, Ill., Charles C Thomas, 1958.

23) Forbes, J. C. : Effect of thyroxine on neutral fat and cholesterol content of body and liver of rats, Endocrinology, 35 : 126, 1944.

24) Frederickson, D. S., Loud, A. V., Hinkelman, B. T., Schneider, H. S. and Frants, I. D. :

The effect of ligation of the common bile duct on cholesterol synthesis in the rat, J. Expr. Med., $99:$ 43, 1954.

25）藤井尋造 : 実験的 Alloxan 糖尿病における歯周 組織の病理組織学的研究, 日歯医誌, $13: 1$, 昭 和 35 年.

26) Glickman, I. : The relation of experimental diabetes to periodontal disease, Am. J. Orth. \& Oral Surg., 33 : 703, 1947.

27) Glickman, I. : The systemic influence upon bone in periodontium, J. A. D. A., 31 : 1435, 1944.

28) Goldman, H. M. : The effect of dietary protein deprivation and of age on the periodontal tissues of the rat and spider monkey, J. Period., $25: 87,1954$

29) Gottlieb, B. und Orban, B. : Die Veränderungen der Gewebe bei übermässiger Beanspruchen der Zähne, Leipzig, 1931, p. 191.

30) Gresham, G. A. : Independent production of atherosclerosis and thrombosis in rat, Brit. J. Expr. Path., 41 : 395, 1960.

31) Gupta, O. P., Blechman, H. and Stahl, S. S. : Effects of stress on the periodontal tissues of young adult male rats and hamsters, J. Period., $31: 413,1960$.

32) Hartroft, W. S., O’Neal, R. M. and Thomas, W. A. : Pathogenesis of atherosclerosis and myocardial infarction, Fed. Proc., 18, Supple $3: 36,1959$.

33) Heuper, W. C. : General reviews in "atherosclerosis", Arch. Path., 38 : 162, 245, 350, 1944. $39: 51,117,187,1945$.

34) Horlick, L. and Havel, L. : The effect of feeding propylthiouracil and cholesterol on the blood cholesterol and arterial intima in the rat, J. Lab. \& Clinic. Med., 33 : 1029, 1948.
35) Kendall, F. E. : Cholesterol metabolism and arteriosclerosis in "Combined stoff clinics", Am. J. Med., 6 : 114, 1949.

36) Komori, A. : Histological studies of the influence of occlusal function on the periodontal tissues of alloxan diabetic rats, The Bull. Tokyo M. \&. D. Univ., 11 : 207, 1964.

37) Marx, W., Marx, L. and Shimoda, F.: Thyroid hormone and tissue cholesterol distribution, Proc. Soc. Expr. Biol. Med., 73 : 295, 1950.

38) Mitchell, D. F. : The effect of propylthiouracil on the periodontium of the hamster, J. D. Res., $29: 386,1950$.

39) Mitchell, D. F. : The production of periodontal disease in the hamster as related to diet, coprophagy and maintenance factors, J. D. Res., 29 : 732, 1950.

40）宮崎吉夫, 石川梧朗, 秋吉正豊 : 口腔病理学, 後編（最新歯科全書 4 巻）京都, 東京, 永末書 店, 昭和 33 年.

41) Naimi, S., Goldstein, R., Nothman, M. M., Wilgram, G. F. and Proger, S. : Cardiovascular lesions and changes in blood coagulation and fibrinolysis associated with diet induced lipemia in the rat., J. Clinc. Invest., $41: 1708$, 1962.

42）岡本耕造 : 退行性病変 (物質代謝障害), “病理 学総論” ’ら, 鈴江懐, 小林忠義編集, 東京, 医学書院, 昭和 35 年.

43) Okey, R. E. : Effect of cholesterol feeding upon lipid of rat liver, Proc. Soc. Expr. Biol. \& Med., 30 : 1003, 1933.

44) Page, I. H. and Brown, H. B. : Induced hypercholesterolemia and atherogenesis, Circulation, $6: 681,1952$.

45) Patek, P. R., Bernick, S., Ershoff, B. H. and Wells, A. : Induction of atherosclerosis by cholesterol feeding in the hypophysectomized rat, Am. J. Path., 42 : 137, 1963.

46) Preissecker, O. : Beeinflussung des Periodontiums durch experimentelle Entlastung, Ztschr. für Stomat., $29:$ 442, 1931.

47) 佐伯 誠：ラットの大臼歯の歯周組織における 実験的癈用性萎縮の発生過程およびその修復過 程について，口病誌，26:317，昭和 34 年.

48) 桜岡歌四郎：マウスの歯周組織に及ぼす Cortison, 蛋白欠乏食および飢餓の影響について， 口病誌, $26: 760$, 昭和 34 年.

49) Sandler, H. C. and Glickman, I. : The effects of local irritation on the periodontium of protein deprived rats, J. D. Res., $34: 723,1955$. 
50) Scott, R. F., Alousi, K., Goodale, F., Gittelsohn, A. M. and Thomas, W. A. : Dietary lipids, thrombosis and clot-lysis, Arch. Path., $71: 714,1961$.

51) Shklar, G., Cohen, M. M. and Yerganian, G. : A histopathologic study of periodontal disease in the Chinese hamster with hereditary diabetes mellitus, J. Period., 33 : 14, 1962.

52) Siperstein, M. D. and Chaikoff, I. L. : Conversion of cholesterol to bile acids, Fed. Proc., $14: 767,1955$.

53) Sognnaes, R. F. : Experimental production of periodontal disease in animals fed on a purified, nutritionally adequate diet. J. D. Res., 26 : 475, 1947.

54) Sperry, W. M. and Stoyanoff, S. : Effects of long-continued cholesterol feeding in rats, J. Nutr., $9: 131,1935$.

55) 竹内 卭, 飯島宗一, 渡辺五郎 : 最新病理学一構 造と機能一, 東京, 文光堂, 昭和 38 年.

56) Thomas, W. A. and Hartroft, W. S. : Myocardial infarction in rats fed diets containing high fat, cholesterol, thiouracil and sodium cholate, Circulation, $19: 65,1959$.

57）戸枝一夫，上野和之，山本 肇：コレステリン投 与白鼠の歯周組織の変化について (第二報) (抄), 口科誌, $13: 323$, 昭和 39 年.

58）上野和之，戸枝一夫，山本 肇：コレステリン投 与白鼠の歯周組織の変化について(第一報) (抄), 歯基礎誌, 5 巻 1.2 号 : 41 , 昭和 38 年.
59) Wells, A. F. and Ershoff, B. H. : Effect of cholesterol feeding on plasma and liver cholesterol levels in hypophysectomized rat, Proc. Soc. Expr. Biol. \& Med., 109 : 643, 1962.

60) Wilgram, G. F. : Experimental atherosclerosis and cardiac infarcts in rats, J. Expr. Med., 109 : 293, 1959.

61) Wissler, R. W., Eilert, M. L., Schroeder, M A. and Cohen, L. : Production of lipomatous and atheromatous arterial lesions in the albino rat. Arch. Path., 57 : 333, 1954.

62) Woods, J. W., Penick, G. D. and Hill, C. : Warfarin and diet-induced lipoidosis in rats, Arch. Path., 78 : 234, 1964.

63) 山本 勉: フマール酸およびュレステリン投与に よる実験的動脈硬化症の研究，とくにコレステ リン型動脈硬化症の成因の検討, 日病会誌, 46 : 28 , 昭和 32 年.

64）吉田富三，武田勝男：病理学各論中巻，東京, 南山堂, 昭和 32 年.

65) Yuasa, D. : Über die experimentelle Cholesterinkrankheit bei Omnivoren, Beitr. path. Anat. u. allg. Path., $80: 570,1928$.

66）弓狩康三，須田正己：遊離脂肪酸によるシ口ネ ズミ肝グルコキナーゼの阻害, 生化学, 37(9) : 544, 1965.

67) Zak, B. : Simple rapid microtechnic for serum total cholesterol, Am. J. Clinc. Path., 27 : 583, 1957. 